\title{
Geçici Eğitim Merkezlerinde Görev Yapan Suriyeli ve Türk Sınıf Öğretmenlerinin Öğretmenlik Deneyimleri Üzerine Bir Yașam Öyküsü Araștırmasi*
}

\author{
Sümeyye Evran ${ }^{1}$, Martina Riedler ${ }^{2}$, \& Mustafa Yunus Eryaman ${ }^{3}$
}

\begin{abstract}
Özet: $\mathrm{Bu}$ araştırmada geçici eğitim merkezlerinde görev yapan Türk ve Suriyeli sınıf öğretmenlerinin öğretmenlik deneyimleri üzerine bir yaşam öyküsü araştırması yapılarak öğretmenlerin geçici eğitim merkezindeki tecrübelerinin günlük yaşantılarında ve meslek hayatlarında ne gibi değişikliklere yol açtığını belirlemek amaçlanmıştır. Araştırmanın çalışma grubunu İstanbul'da Suriyeli sığınmacıların yoğun olarak yaşadığı bir bölgede bulunan bir geçici eğitim merkezinde görevli 4 Türk, 4 Suriyeli sınıf öğretmeni oluşturmaktadır.

Çalışmada nitel araştırma desenlerinden olan Yaşam Öyküsü deseni kullanılmıştır. Araştırmada nitel araştırmalarda en yaygın olarak kullanılan veri toplama tekniklerinden olan görüşme ve gözlem teknikleri uygulanmıştır. Verilerin analizinde içerik analizi kullanılmıştır. Öğretmenlere yapılan görüşmelerde geçici eğitim merkezindeki deneyimleri ve bu deneyimlerin günlük yaşantılarında ve meslek hayatlarında ne gibi değişikliklere yol açtığına dair sorular sorulmuş ve örneklendirerek cevaplamaları istenmiştir.
\end{abstract}

Anahtar Kelimeler: Geçici Eğitim Merkezi, Yaşam Öyküsü, Sınıf Öğretmenleri, Entegrasyon, PICTES

Geliş Tarihi: 03.01.2020 - Kabul Tarihi: 29.02.2020 - Yayın Tarihi: 29.06.2020

DOI: $10.29329 /$ mjer.2020.258.12

\section{A Life Story Inquiry on Teaching Experiences of Syrian and Turkish Teachers Working in a Temporary Education Center}

\begin{abstract}
The purpose of this study was to explore the teaching experiences of Turkish and Syrian classroom teachers working in a Temporary Education Center in Turkey. By analyzing the narratives of these teachers on their lived experiences in the Center, the study further focused on how these experiences transformed the teachers' daily lives and professional identities.
\end{abstract}

\footnotetext{
* Bu çalışma "Geçici eğitim merkezlerinde görev yapan Suriyeli ve Türk sınıf öğretmenlerinin öğretmenlik deneyimleri üzerine bir yaşam öyküsü araştırması" adlı yükseklisans tezinden üretilmiştir.

${ }^{1}$ Sümeyye Evran, Sınıf Eğitimi, Çanakkale Onsekizmart Üniversitesi, ORCID: 0000-0002-4928-082X

Correspondence: sumeyyeevran@gmail.com

${ }^{2}$ Martina Riedler, Assoc. Prof. Dr., Art Education, Çanakkale Onsekiz Mart University, ORCID: 0000-0001-5207-9644

${ }^{3}$ Mustafa Yunus Eryaman, Prof. Dr., Elementary Education, Canakkale Onsekiz Mart University, ORCID: 0000-00024214-1202
} 
Life Story Inquiry as a qualitative research method was employed to collect and analyze the data. Life Story research pays special attention to the narrative knowledge generated and constructed through the stories individuals tell about their lived experiences and explores the concept of 'narrative knowing' (Bruner, 1987).

The study group consisted of 4 Turkish and 4 Syrian classroom teachers working at a Temporary Education Center in Turkey. Interviews and observations were used as qualitative data collection techniques to generate the data. Content analysis technique was used for data analysis.

Keywords: Temporary Education Center, Life Story Research, Classroom Teachers, Integration, PICTES

\section{GİRIŞ}

2010 senesinde Orta Doğuda ortaya çıkan ve Arap baharı olarak adlandırılan siyasi olayların Suriye Arap Devleti'ne sıçraması sonucunda Tunus, Mısır, Libya gibi ülkelerin yanında Suriye hükümeti ve halk arasında da bazı anlaşmazlıklar ortaya çıkmış, gitgide ilerleyen bu gerginlik Ocak 2011 tarihinde Suriye'de bir iç savaşın kıvılcımlarını tetiklemiştir. Ülkelerindeki bu iç savaştan kurtulmak isteyen Suriye vatandaşları başta Türkiye, Filistin, Mısır olmak üzere birçok ülkeye göçler gerçekleştirmeye başlamıştır (Eryaman \& Evran, 2019; Özdemir, 2017).

2011 yılının Nisan ayında ilk olarak 250 kişi civarında kişiyle ülkemize giriş yapmaya başlayan Suriyelilerin sayısının AFAD verilerine göre günümüzde kayıtlı ve kayıt dışı sığınmacılar dâhil olmak üzere 4 milyona yaklaştığı düşünülmektedir. $\mathrm{Bu}$ derece ciddi bir kitleyle gerçekleşen bu göç ülkemizde bazı sorunların oluşmasına sebep olmuştur.

Türkiye'ye göç eden Suriyeli mültecilerin önemli bir kısmının çocuk olması, barınma, sağlık gibi ihtiyaçların yanında eğitim ihtiyacının da gündeme gelmesine neden olmuştur. Suriyeli öğrencilerin eğitimine yönelik belediyelerin, vakıf ve derneklerin yürüttükleri birçok proje hali hazırda bulunmaktadır. Fakat ülke geneli düşünüldüğünde Suriyeli çocukların Türk eğitim sistemine entegrasyonunu en iyi ve kapsamlı şekilde desteklemeyi amaçlayan uygulama Milli Eğitim Bakanlığ1 ve Avrupa Birliğinin 2016 Aralık ayından itibaren ortak yürüttüğ̈̈ 'Suriyeli Öğrencilerin Türk Eğitim Sistemine Entegrasyonunu Desteklenmesi Projesi'dir.

$\mathrm{Bu}$ projede çalışmak üzere ilk etapta 2016 Kasım ayında Sınıf öğretmenliği, Türkçe öğretmenliği ve Türk dili ve Edebiyatı bölümlerinden KPSS ve mülakat puanları göz önünde bulundurularak alım yapılmış ve ihtiyaca göre bu alımlar yinelenmiştir. Suriyeli öğreticilerde ise Suriye'de öğretmen olanlara öncelik tanınmakla birlikte gönüllülükleri de esas alınarak geçici eğitim merkezlerinde görevlendirilmeye başlanmıştır. Her iki öğretmen grubu için de farklı bir eğitim ortamı olması, alışılmadık deneyimleri de muhakkak beraberinde getirmiştir. Suriyeli mültecilerin ülkemizde yaşadıkları sıkıntıların hukuk, sağlık, eğitim noktalarındaki boşluklarını araştıran çalışmalara ilaveten farklı bir bakış açısı olarak geçici eğitim merkezlerinde görev yapan Suriyeli ve Türk sınıf öğretmenlerinin eğitim sürecindeki deneyimleri üzerine bir araştırmaya da ihtiyaç duyulmuştur. 


\section{Araștırmanın Amacı}

$\mathrm{Bu}$ araştırmanın genel amac1; Suriyeli Öğrencilerin Türk Eğitim Sistemine Entegrasyonun Desteklenmesi Projesi kapsamında geçici eğitim merkezlerinde görev yapan sınıf öğretmenliği lisansından mezun Türkçe öğreticilerinin ve Suriyeli öğretmenlerin çalışma sürecinde kazandıkları deneyimlere ulaşarak bu deneyimlerin eğitim anlayışlarına ve öğretmenliğe bakışlarına, yaşamlarına ne şekilde etki ettiğini saptamaktır.

\section{YÖNTEM}

Araştırmada nitel araştırma desenlerinden olan yaşam öyküsü araştırma deseni uygulanmıştır. Yaşam öyküsü, kişinin hayatının kritik ve önemli bir noktasında yaşadığı olayların hayatına ne derece etki ettiğini anlayabilme ve olayları yaşayan birinin gözünden edinip yorumlama açısından derinlemesine yol izleyen ve oldukça önemli bir araştırma desenidir (Bruner, 1987; Baykara Acar, 2004).

\section{Katılımcılar}

Odak öğretmen Mustafa. Geçici eğitim merkezindeki Türkçe öğreticilerimizden Mustafa öğretmen, Türkiye'nin doğu bölgesindeki bir şehirde dünyaya gelmiş, 24 yaşında, bekâr ve erkek bir öğretmendir. Lisesini Anadolunun batısındaki bir şehirde okuyup mezun olan öğretmen, üniversitesini 4 yıllık sınıf öğretmenliği bölümünü okuyarak tamamlamıştır.

Öncesinde herhangi bir öğretmenlik deneyimi olmayan Mustafa öğretmen PİCTES kapsamında ilk olarak Kız İmam Hatip Lisesinde iki yıl çalıştıktan sonra bir yıldır da araştırma yapılan geçici eğitim merkezinde çalışmaktadır. TÖMER belgesi bulunan Mustafa öğretmen 47 öğrencinin dersine girmektedir.

Odak öğretmen Melek. Geçici eğitim merkezindeki Türkçe öğreticilerimizden Melek öğretmen, Türkiye'nin doğu bölgesinde dünyaya gelmiş 26 yaşında, bekâr ve kadın bir öğretmendir. Lisesini Türkiye'nin batısı bölgesinde okuyup mezun olan öğretmen, üniversitesini 4 yıllık sınıf öğretmenliği bölümünü okuyarak tamamlamıştır.

Öncesinde herhangi bir öğretmenlik deneyimi olmayan Melek öğretmen PİCTES kapsamında üç yıldır araştırma yapılan geçici eğitim merkezinde çalışmaktadır. TÖMER belgesi bulunan Melek öğretmen 50 öğrencinin dersine girmektedir.

Odak öğretmen Fatma. Geçici eğitim merkezindeki Türkçe öğreticilerinden Fatma öğretmen, Türkiye'nin doğu bölgesinde dünyaya gelmiş, 26 yaşında, bekâr ve kadın bir öğretmendir. Lisesini batı bölgesinde okumuş olan öğretmen, üniversitesini 4 yıllık sınıf öğretmenliği bölümünü okuyarak tamamlamıştır. Öncesinde herhangi bir öğretmenlik deneyimi olmayan Fatma öğretmen üç yıldır PİCTES kapsamında araştırma yapılan geçici eğitim merkezinde çalışmaktadır. TÖMER belgesi bulunan Fatma öğretmen 47 öğrencinin dersine girmektedir. 
Odak öğretmen Emre. Geçici eğitim merkezindeki Türkçe öğreticilerimizden Emre öğretmen, Türkiye'nin doğu bölgesinde dünyaya gelmiş, 25 yaşında, erkek ve bekâr bir öğretmendir. Lisesini Türkiye'nin batı bölgesindeki bir şehirde okuyup mezun olan öğretmen, üniversitesini 4 yıllık sınıf öğretmenliği bölümünü okuyarak tamamlamıştır.

Öncesinde herhangi bir öğretmenlik deneyimi olmayan Emre öğretmen PİCTES kapsamında iki yıl Kız Anadolu İmam Hatip Lisesinde çalıştıktan sonra bir yıldır da araştırma yapılan geçici eğitim merkezinde çalışmaktadır. TÖMER belgesi bulunan Emre öğretmen 40 öğrencinin dersine girmektedir.

Odak öğretmen Ali. Geçici eğitim merkezi Suriyeli öğreticilerden Ali öğretmen, 32 yaşında erkek bir öğretmendir. Öğretmen üniversitesini 4 yıllık sınıf öğretmenliği bölümünü okuyarak tamamlamıştır. Ali öğretmen Suriye'de iki yıllık sınıf öğretmenliğinden sonra Türkiye’ye göçmek zorunda kalmış ve Türkiye'de çeşitli okullarda Suriyeli öğrencilerle çalışmıştır. Bir yıldır da araştırma yapılan geçici eğitim merkezinde sınıf öğretmeni olarak çalışmaktadır. Türkiye'ye 2014’te ailesiyle göç eden Ali öğretmen 40 öğrencinin dersine girmektedir.

Odak öğretmen Ayşe. Geçici eğitim merkezi Suriyeli öğreticilerinden Ayşe öğretmen, 24 yaşında kadın bir öğretmendir. Öğretmen 4 yıllık sınıf öğretmenliği bölümünü mezunudur. Türkiye’ye 2015 senesinde ailesiyle göç eden Ayşe öğretmen 40 öğrencinin dersine girmektedir. Türkçeyi halk eğitim merkezlerinde verilen Türkçe kursları aracıllı̆ıyla öğrenmiştir.

Odak öğretmen Mehmet. Geçici eğitim merkezi Suriyeli öğretmenlerimizden Mehmet öğretmen, 24 yaşında erkek bir öğretmendir. Üniversitesini eğitim fakültesinde 4 yıllık sınıf öğretmenliği bölümünü okuyarak tamamlamıştır. Türkiye'ye 2012 senesinde ailesiyle göç eden Mehmet öğretmen, 45 öğrencinin dersine girmektedir. Türkçeyi halk eğitim merkezlerinde verilen Türkçe kursları aracılığıyla ve yakın çevresindeki Türk arkadaşlarının yardımıyla öğrenmiştir.

Odak öğretmen Zeynep. Geçici eğitim merkezi Suriyeli öğretmenlerimizden Zeynep öğretmen, 28 yaşında kadın bir öğretmendir. Üniversitesini eğitim fakültesi 4 yıllık sınıf öğretmenliği bölümünü okuyarak tamamlamıştır. Zeynep öğretmen Suriye'deki 2 yıllık sınıf öğretmenliğinden sonra Türkiye'ye göçmek zorunda kalmış ve daha sonra araştırma yapılan geçici eğitim merkezinde çalışmaya başlamıştır. Türkiye’ye 2015 senesinde ailesiyle göç eden Zeynep öğretmen 37 öğrencinin dersine girmektedir.

\section{Veri Toplanması ve Analizi}

Araştırmada nitel araştırmalarda en yaygın olarak kullanılan veri toplama tekniklerinden olan görüşme ve gözlem teknikleri uygulanmıştır. Verileri toplamak amacıyla görüşme formu oluşturulmuştur. Araştırma için daha çok mesleki tecrübeye sahip öğretmenleri seçmeye dikkat edilse de Suriyeli öğretmenlerde özellikle Türkçeye kendini ifade edebilecek kadar hâkim olması ve kendini 
yazarak da ifade ediyor olabilmesine dikkat edilmiştir. Gözlem yaparken bazı konuları netleştirmek için öğretmenlerle tenefüs aralarında yapılandırılmamış görüşmeler de gerçekleştirilmiştir.

Görüşme formu İstanbul'da Suriyeli sığınmacıların yoğun olarak yaşadığı bir ilçede bulunan geçici eğitim merkezindeki 4 Türk, 4 Suriyeli öğreticiye uygulanmıştır.

Nitel araştırmalarda kullanılan analiz çeşitlerinden ilki olan betimsel analiz araştırmaya daha yüzeysel yaklaşırken içerik analizi daha derin, olayları kavramlarla açıklayan bir sonuca ulaştırmaktadır. İçerik analizinin esas hedefi elde edilen verileri açıklayabilecek kavramlara ve ilişkileri ortaya çıkarmaktır.(Yıldırım ve Şimşek, 2016)

Araştırmada içerik analizinin uygulanmasının nedeni elde edilen verilerin yardımıyla yeni kavramlara ulaşmak ve verilerin içerisinde saklı olabilecek yeni problem veya gerçekleri öğrenmektir.

Yapılandırılmış görüşme formları, diğer görüşmelerin çıtılları ve gözlem raporları analiz edilerek kodlamalar gerçekleştirilmiş ve temalar belirlenmiştir.

Tablo 1.1. Verilerin Kodlanmış Hali

\begin{tabular}{|c|c|c|c|}
\hline Melek Öğretmen & Fatma Öğretmen & Mustafa Öğretmen & Emre Öğretmen \\
\hline Dil sorunu & Dil Sorunu & Dil Sorunu & Dil Sorunu \\
\hline Suriyeli Alg1s1 & Suriyeli Algisı & Suriyeli Alg1sı & Suriyeli Algisı \\
\hline Materyal eksikliği & Materyal & Tecrübe Eksikliği & Yasal Haklar \\
\hline $\begin{array}{l}\text { Külttürel Zenginlik } \\
\text { Tecrübe eksikliŏi }\end{array}$ & Tecrübe Eksikliği & & \\
\hline Ayşe Öğretmen & Mehmet Öğretmen & Zeynep Öğretmen & Ali Öğretmen \\
\hline Dil Sorunu & Dil Sorunu & Aile Faktörü & Materyal Eksikliği \\
\hline Materyal Eksikliği & Yasal Haklar & Materyal Eksikliği & Yasal Haklar \\
\hline Ekonomik Faktörler & Disiplinsizlik & Dil Sorunu & Etnik Farklılıklar \\
\hline Stres & Materyal Eksikliği & Etnik Farkl11ıklar & Dil Sorunu \\
\hline Hoşgörü & Etnik Farklılıklar & Kültürel Benzerlikler & Hoşgörü \\
\hline Dinsel Faktörü & Ekonomik Faktörler & Gelecek Kaygis1 & Din Faktörü \\
\hline Savaşın İzleri & Hoşgörü & Memleket Özlemi & Aile Faktörü \\
\hline Yasal Haklar & Dinsel Faktörü & Devamsızlık & Zeka \\
\hline & Savaşın İzleri & & Memleket Özlemi \\
\hline
\end{tabular}

Tablo 1.2.Veri Kodlarının Frekans Tablosu

\begin{tabular}{|c|c|c|c|c|c|c|c|c|c|c|c|}
\hline & Katılımcila & & & & & & & & & Toplam & $\%$ \\
\hline & Melek & Fatma & Mustafa & Emre & Ayşe & Mehmet & Zeynep & Ali & & 8 & $\% 100$ \\
\hline \multicolumn{12}{|c|}{ GEM'lerde Öğretmen Olmak } \\
\hline Hoşgörü & & & & & 1 & 1 & & & 1 & 3 & $\% 37,5$ \\
\hline Din & & & 1 & & 1 & 1 & & & 1 & 4 & $\% 50,0$ \\
\hline Savaş İzleri & & & & 1 & 1 & & 1 & & & 3 & $\% 37,5$ \\
\hline Gelecek Kaygis1 & & & & & & & 1 & & & 1 & $\% 12,5$ \\
\hline Zeka & & & & & 1 & 1 & & & 1 & 3 & $\% 37,5$ \\
\hline Aile Faktörü & 1 & 1 & & & 1 & & 1 & & 1 & 5 & $\% 62,5$ \\
\hline \multicolumn{12}{|l|}{ Dil ve Uyum } \\
\hline Dil Sorunu & 1 & 1 & 1 & 1 & 1 & 1 & 1 & & 1 & 8 & $\% 100$ \\
\hline Suriye Algis1 & 1 & 1 & & 1 & & & & & & 3 & $\% 37,5$ \\
\hline Kültürr & 1 & 1 & 1 & 1 & & 1 & 1 & & & 6 & $\% 75,0$ \\
\hline Stres & & & & & 1 & & & & & 1 & $\% 12,5$ \\
\hline
\end{tabular}




\begin{tabular}{|c|c|c|c|c|c|c|c|c|c|c|}
\hline \multicolumn{11}{|c|}{ GEM'lerde Karșılașılan Eksiklikler ve Yasal Sıkıntılar } \\
\hline Materyal Eksikliği & 1 & 1 & \multirow{5}{*}{1} & & 1 & 1 & 1 & 1 & 6 & $\% 75,0$ \\
\hline Yasal Haklar & & 1 & & 1 & 1 & 1 & & 1 & 5 & $\% 62,5$ \\
\hline Disiplinsizlik & & & & & 1 & 1 & 1 & 1 & 5 & $\% 62,5$ \\
\hline Etnik Farklılıklar & & & & & & 1 & 1 & 1 & 3 & $\% 37,5$ \\
\hline Devamsızlık & & & & & & & 1 & & 1 & $\% 12,5$ \\
\hline \multicolumn{11}{|c|}{ Mesleki Deneyim ve Eğitim Eksikliği } \\
\hline Tecrübe Eksikliği & 1 & 1 & 1 & 1 & & & & & 4 & $\% 50,0$ \\
\hline Memleket Özlemi & & & 1 & & & & 1 & 1 & 3 & $\% 37,5$ \\
\hline
\end{tabular}

Geçici Eğitim Merkezindeki sınıf öğretmenleri ile öğretmenlik deneyimleri üzerine yapılan bu araştırmada elde edilen verilerin analizleri sonucunda şu ana temalara ulaşılmıştır: 1. Geçici Eğitim Merkezinde Öğretmen Olmak 2. Dil ve Uyum; 3. Geçici Eğitim Merkezlerinde Karşılaşılan Eksiklikler ve Yasal Sıkıntılar; ve 4.Mesleki Deneyim ve Eğitim Eksikliği.

\section{ARAŞTIRMA BULGULARI}

\section{GEM' de Öğretmen Olmak}

$\mathrm{Bu}$ bölümde geçici eğitim merkezlerindeki sınıf öğretmenleriyle yapılan görüşmeler ve gözlemler sonucu geçici eğitim merkezinde öğretmen olmanın tanımına ve işleyişe yönelik verilere yer verilmiştir.

Odak katılımcı Melek öğretmen geçici eğitim merkezlerini devlet okullarına kıyasla daha çok problemin ortaya çıktığı kurumlar olarak tanımlamıştır. (Gözlem, Melek, s:1-2, 03.05.2019)

Öğretmen geçici eğitim merkezinde öğretmen olmak hakkında ise;"' GEM' de öğretici olmak Türk okullarına göre daha yorucu çünkü Türk okullarında öğrenci daha kolay öğreniyor. Türk öğrenciler sizi daha az yoruyor. Anlatım daha kolay. Fakat Suriyelilere ders anlatmak daha yorucu ama bir öğretmen olarak millet ayrımı yapmanın doğru olduğunu düşünmüyorum. İşim doğruyu en iyi şekilde öğretmek, gerektiği gibi yaptığımı düşünüyorum" cevabını vermiştir (Görüşme, Melek, s:1-2, 06.05.2019).

Öğretmenler odasında yaptığımız görüşmede Melek öğretmen, geçici eğitim merkezlerinin çocukların Suriye'yi unutmamaları için faydalı olsa da onların Türkiye'ye entegrasyonunu geciktirdiğini ve bu nedenle de mesleki doyuma ulaşamadığını dile getirmiştir (Yapılandırılmamış Görüşme, Melek, s:1-2, 03.05.2019).

Bir başka Türkçe öğreticisi Fatma öğretmen ise geçici eğitim merkezinde öğretmen olmak hakkında; 'Gem'de öğretici olmak aslında diğer öğretmenlik alanlarını düşündüğümüzde oldukça farklı bir durum. Ben sabahtan öğlene kadar Türkçeden daha çok Arapça duyuyorum. Çok dilli bir platformda öğretmen olmak oldukça güzel bir duygu. Bir şey anlatmaya çalıştığımızda en sade şekliyle anlatabiliyoruz, diğer türlü havada kalıyor. Bu durum öğretmenliğe bakışımda da aslında çocuklar için en güzel öğretme yönteminin sadeleştirip onların anlayabilecekleri şekilde düzeltmek olduğunu gösterdi. Daha önce hep dersime girer anlatır çıkarım, anlayan anlar diyordum. Sonradan 
gördüm ki öyle değil onların anlayabileceği şekilde çok indirgiyorum konuyu" şeklinde görüş vermiş̧tir (Görüşme, Fatma, s:1-2, 10.05.2019)

Fatma öğretmen ayrıca GEM'deki ilk günleri hakkında şu bilgileri vermiştir: "GEM' de çalışmaya başladığımda sanki ben Suriye'ye gitmişim gibi hissetmiştim. Binada Türkçe konuşan bir müdürümüz bir de öğretmen arkadaşlarımız var. Ama yavaş yavaş alışıyor insan, diyalog kurdukça aslında sadece dillerin farklı olduğunu gördüm. Zorlandığım noktalar bunlar oldu ve zaman geçtikçe düzeldi şükür.'” (Görüşme, Fatma, s:2, 10.05.2019)

Fatma öğretmen kendisinin GEM'e epey bir süre alışamadığını sonrasında ise çok uluslu ortamda öğretmen olmanın kendisine çok güzel tecrübeler kattığını ve ders saatleri sonrası bile okulda kalmayı tercih ettiğini ifade etti. Sonrasında birlikte derse girdiğimiz Fatma öğretmen sınıfta oldukça rahat bir şekilde mevsimler konusunu işledi. Türkçesi iyi olan öğrencilerin anladıklarını arkadaşlarına Arapça anlatmasına müsaade etmeyen Fatma öğretmen, öğrencileri kendi aralarında dahi Türkçe konuşma konusunda uyardı. (Gözlem, Fatma, s:1-2, 09.05.2019)

Odak Türkçe öğreticisi Mustafa öğretmen ise geçici eğitim merkezinde öğretmen olmak hakkında şu ifadeleri kullanmıştır: "GEM' ler sadece resmi okullar bünyesinde mültecilere verilen eğitimi resmi hale getirmek için açılan kurumlardır. Suriyeli öğrencilerle iletişime geçerken kelimelerimde daha seçici oluyorum. Yaş ile anlama arasında olduğunu düşündüğüm doğru orantının aslında o kadar da kesin olmadığını gördüm eğitim hayatıma çok ayrı bir bakış kattı. Konuşma hızımda yavaşlama, kendimi daha iyi ifade etme sınırlı kelime sayısıyla iletişim kurma becerisi kazandım. Okul ve okul dışı ortamlar arasında geçiş yapmakta biraz zorlanıyorum." (Görüşme, Mustafa, s:1-2, 02.05.2019).

Mustafa öğretmenin sadece kendi öğrencileri tarafından değil okuldaki diğer öğrenciler tarafından da sevildiği özellikle ders aralarında koridorlarda görülebiliyordu. Öğrencilerinin en çok kendilerine şaka yapılmasından hoşlandığını söyleyen Mustafa öğretmen; 'Beni öğretmen olarak değil de ağabey olarak görüyorlar.' dedi. Öğretmenler odasındaki sohbetlerimizde daha çok işleyişsten ve bu merkezlerin çok güzel bir amaçla kurulsa da bazı noktalarda sıkıntıların olduğundan da söz etti (Gözlem, Mustafa, s:1-2, 01.05.2019).

Geçici eğitim merkezindeki bir diğer Türkçe öğreticisi Emre öğretmen GEM’ de öğretmen olmak hakkındaki görüşünü şu şekilde beyan etti: “GEM' de öğretmen olmak diğer öğretmenliklere göre biraz daha zor diye düşünüyorum. Çünkü burada çoğunluk Suriyeli. Ve öğrenciler okul içinde Türkiye'de olduklarının çok da farkında değiller. Gem'de öğreticilik akıntıya karşı kürek çekmek gibi. Öğrenci sabahtan beri Arapça konuşuyor, derslerini Arapça görüyor, hocalarıyla Arapça konuşuyor sonra biz derse girip Türkçe öğretmeye çalışıyoruz. Zor iş yani. Şimdi öğrencilerim, velilerim oldular ve ortaya bir şeyler çıkarmaya çalışıyoruz. Babası olmayan, ekonomik anlamda zor durumda olan öğrencilerimiz var mesela onların acısını paylaşıyoruz. Zaman geçtikçe mutluluklar, üzüntüler 
paylaşılma başlandı.' (Görüşme, Emre, s:1, 08.05.2019). Emre öğretmen eğitimin öncelikle öğrencinin ve öğretmenin sağliklı olmasından geçtiğini düşünüyordu: “Öğrencilerimiz savaş görmüş, belki de travma geçirmiş çocuklar. Öncelikle onlara dil öğretmekten ziyade, psikolojik açıdan yardımc1 olmalıyız diye düşünüyorum." (Görüşme, Emre, s:2, 08.05.2019). Her ne kadar Emre öğretmenin diğer meslektaşları ile çok fazla iletişimde olmadığı ve öğrencileriyle arasındaki ilişkinin ise sınırlı olduğu gözlemlense de diğer sınıflara kıyaslandığında öğrencilerinin daha disiplinli olduğu belirgindi. Birebir konuşmalarımızda GEM'in proje kapsamındaki üçüncü okulu olduğunu söyleyen Emre öğretmen, gittiğimiz her okulda yeni deneyimler kazanarak daha iyi bir öğretmen olduğu yorumunda bulundu (Yapılandırılmamış Görüşme, Emre, s:1, 07.05.2019).

Suriyeli öğretmenlerin Türkçeleri iyi olsa da öğrencilerle Arapça konuştukları için kendi aralarındaki konuşmaları anlamak oldukça zordu. Sınıflarda ise diğer Türk öğretmenlere kıyasla Suriyeli öğretmenlerin dersinde daha çok disiplin ve sessizlik olduğunu gözlemlendi. (Gözlem, Ayşe, $\mathrm{s}: 1,15.05 .2019)$.

Suriyeli öğreticilerden Ayşe öğretmenin GEM hakkındaki görüşü şu şekildeydi: "Bu okul güzel ama Suriyeli ve Türk çocuklar arasında daha çok iletişim lazım. Öğretmenler arasında arkadaşlık lazım. Burası Türk-burası Suriyeli var. Sosyallik az yani. GEM'i önceden sevmiyordum ama şimdi iyi. Çocuklarda problem var, terbiyelerinde problem var. Başkaları fabrikada çalışıyor, başkalarını işe almadılar bu yüzden okulda çalışmak güzel. Bu yıl çok rahat, öğretmenlerle bu yıl çalışmak daha güzel, geçen y1l çok zordu. Burada düzen çok daha iyi. Suriye'de öğrenciler ben Halepliyim, ben kürdüm, ben kırmanca, ben Sünni diye ayrılıyordu şimdi Türkiye'de öğrencilerin hepsi beraber. Burada ayrılık yok. Öğretmenlikte Türk arkadaşlar oldu, o güzel. Suriyeli çocuklar için bizim gibi çalışıyorlar. Türkiye'ye geldiğimde öğrencilerin hali daha kötüydü, çok üzüldüm. Öğrencilerin sıkıntılarını hallediyorum, sadece öğretmenlik değil psikolojilerine de yardım ediyorum." cevabını vermiş̧ir. (Görüşme, Ayşe, s:1-3, 16.05.2019).

Ayşe öğretmen öğrencileri tarafından oldukça sevilen, teneffüs aralarında dahi öğrencileriyle ilgilenen bir öğretmendi. Öğrencilerinin Suriye'de eğitim görselerdi çok daha başarılı olacaklarını düşünen ama okulsuz kalmalarındansa GEM'e gelmelerinin çok daha faydalı olduğunu söyleyen Ayşe öğretmen, öğretmenler odasına geçtiğinde de sosyal ilişkiler kurabilen bir öğretmendi. (Gözlem, Ayşe, s:1, 15.05.2019).

Suriyeli bir diğer öğretici Mehmet öğretmen GEM deneyimlerini şu şekilde özetlemiştir: ' Öğretmenler kardeş gibiler, merhamet var, muhabbet var. Her şey kolay mesai kolay, Benim için para noktasında çok iyi oldu. Suriyeliler hemen iş bulamıyor. Onun için güzel oldu. Okul içinde Türk arkadaşlar oldu. Türklerle arkadaş oldum. Okulda çalışmasam bu kadar Türk tanımazdım mesela.', (Görüşme, Mehmet, s:1, 20.05.2019). 
Geçici eğitim merkezi dişında da oldukça aktif olan Mehmet öğretmen TRT'de bazen programlarda yer aldığını ama orada genellikle Arapça konuştuğunu ifade etti. Öğretmen arkadaşlarıyla en güzel ve çıkarsız ilişkileri geçici eğitim merkezinde kurduğunu söyleyen öğretmenin kardeşi de geçici eğitim merkezinde öğrenciymiş. Mehmet öğretmen ders yoğunlunun fazla olmadığını ve dışarıda da işi olmadığında okulda kalmayı tercih ettiğini söyledi. Derslerinden arta kalan zamanlarda idare bölümünde olduğunu ve oradaki Suriyeli arkadaşlarına Türkçe noktasında yardım ettiğini ifade etti (Yapılandırılmamış Görüşme, Mehmet, s:1, 17.05.2019).

Suriyeli bir diğer öğretici Zeynep öğretmen geçici eğitim merkezinde öğretmen olmakla ilgili şu şekilde görüş bildirmiştir: "Mutlu değilim çünkü yapmam gereken şeyleri, öğretmen gereken şeyleri yapamıyorum. Çocukların davranışları doğal değil, hiçbir şekilde eğitim veremiyorum, iletişim kuramıyorum. Tabii ki iş imkânı sağladı aileme yardım açısından. Direkt çalışma imkânı buldum bunun için çok mutluyum. Öğretmenliğe hemen başladım.” (Görüşme, Zeynep, s:2-3, 22.05.2019).

Geçici eğitim merkezindeki diğer Suriyeli öğretmenlere göre daha mutsuz gördüğümüz Zeynep öğretmen genel anlamda çok fazla uyum sağlayamamış gibi görünüyordu. Çok fazla arkadaşının olmadığını gördük. Suriyeli öğretmenlerin öğretmenler odasında özellikle kadın öğretmenler arasında bir kutuplaşma zaten vardı. Zeynep öğretmen içine kapanık sadece dersine girip çıkan bir öğretmendi. (Gözlem, Zeynep, s:1, 21.05.2019).

Ali öğretmen ise geçici eğitim merkezinde öğretmen olmakla ilgili, 'Çalışma saatleri uygun, aynısı Suriye'de de öyle, haftada 27 ders var ama öğretmenin dersi 18 saat. Şimdi 20 tane dersim var önceden 13 taneydi. Gem'de ben rahatım ama rahatsızlı̆̆ın nedeni öğrenciler çok kalabalık. Çocukların çok sıkıntıları var beni rahatsız eden şey bu. 3 yıl öncesinde ders vermiyordum ama şimdilerde eğitim sistemini biliyorum. Ben kendimi çok ağır hissediyordum çalı̧̧madan önce çalışmakla birlikte kendimi daha iyi hissettim. Türk arkadaşlarımız oldu, öğretmenler çok güler yüzlü. Mesela bir yeri bilmiyoruz hemen öğretmen arkadaşlara soruyoruz. Yardımcı oluyorlar. Türkiye'nin geleneklerini okulda yavaş yavaş tanıyoruz. Öğrenciler zaten bizim öğrenciler o konu farklı. Elhamdülillah Türkiye çok güzel. Ben çok şükrediyorum. Suriye'deki çok insan Türkiye'ye gelince çok zorlandı. İş bulamadılar. Ben üç senedir çalışıyorum çalışma arkadaşları güzelse çok güzel oluyor.’ demiştir (Görüşme, Ali, s:2, 14.05.2019).

Ali öğretmen Türk öğretmenlerle daha çok iletişime geçmeye çalışan, Türkçesi oldukça iyi olsa da kendisini geliştirmeye devam eden ve Türkiye’yi merak ettiğini gösteren tavırlar sergileyen bir öğretmendi. Öğrencileri tarafından da oldukça sevilen bir öğretmen olması geçici eğitim merkezi içerisinde güzel zaman geçirmesini sağlıyordu (Gözlem, Ali, s:1, 13.05.2019).

\section{Dil ve Uyum}

$\mathrm{Bu}$ bölümdeki verilerle araştırmacılar geçici eğitim merkezlerindeki dil sorunu hakkında neler düşünüldüğüne ve çok kültürlü ortamda uyumun nasıl gerçekleştiğine dair bulgulara yer vermiştir. 
Geçici eğitim merkezinde en çok göze çarpan unsur dil olarak ortaya çıkmaktaydı. Öğretmenlerin öğrencileriyle diyaloğunu zorlaştıran, anlatılan konunun anlaşılmasını engelleyen ve disiplin sorunlarının ortaya çıkmasına neden olan en önemli unsur öğretmenlerin öğrencilerle ortak dilde buluşamamaları idi.

Görüşmeler ve sohbetler esnasında öğretmenlerin sürekli olarak en çok bu durumdan yakındıkları gözlemlendi. Dil konusunda öğretmenlerin yorumları şu şekildeydi;

Melek öğretmen; "İlk başlarda dillerin anlaşılmasında problem yaşıyorduk, fakat şuan sohbet ediyoruz. Zorlandığım yer Arapça bilmiyor oluşum, fakat Türkçe öğretmekte zorlanmıyorum.” dedi (Görüşme, Melek, s:2, 06.05.2019). Yaşanılan bu dil probleminin çözümüne ilişkin GEM' leri değerlendiren öğretici; 'Türk okullarında yabancı öğrenciler Türkçeyi arkadaşlarından ve öğretmenlerinden daha kolay öğrenirken GEM' lerde çocuklar sürekli Arapçaya maruz kaldığı için Türkçe öğrenmeleri daha zordur. Diğer derslerin de Arapça olarak öğretilmesi çocuklardaki Türkçe öğrenme isteğini en aza indirmiştir.” demiştir (Yapılandırılmamış Görüşme, Melek, s:1-2, 03.05.2019).

Dil problemini aşan ve aşamayan öğrencilerin arasındaki farkı Melek öğretmene soruduğumuzda ise; “Öğrenciye göre değişiyor aslında. Örneğin; okula bir ay önce gelmiş hiç Türkçe bilmiyor ama kendini geliştirip bir ay sonunda iyi Türkçe konuşabiliyor. Fakat başka bir öğrenciye baktığımızda üç yıldır dersi aldığı halde hala sıfır Türkçe. Açıkçası biraz istek meselesi.(9)” cevabını vermiştir (Görüşme, Melek, s:3, 06.05.2019).

Melek öğretmen ile ders sonrasındaki konuşmamızda Arapça bilmeyişini kendisinde eksiklik olarak gördüğü açıkça belli idi. Özellikle çocukların aileleri geldiğinde veya Suriyeli öğretmenlere bir şey anlatmak gerektiğinde anlaşılamamaktan yorulduğunu ifade etti. Öğrencilerin kendi aralarında Arapça konuşmasından da rahatsızlık duyduğunu belirttikten sonra, en iyi öğrenmenin karşılıklı öğrenmeyle gerçekleşeceğini söyledi. (Yapılandırılmamış Görüşme, Melek, s:1-2, 03.05.2019).

Yaşanılan en büyük problemin dil problemi olduğunu ifade eden Fatma öğretmen, "Bir şey anlatmaya çalıştığımızda en sade şekliyle anlatabiliyoruz, diğer türlü havada kalıyor(4)" demiştir (Görüşme, Fatma, s:1, 10.05.2019) Ayrıca somut konularda yorulmadığını ama dil bilgileri gibi soyut bir konuya başlamadan önce tedirgin olduğunu paylaştı. Öğrencilerin dil düzeylerinin de aynı olmadığına değinen öğretmen, "bazısının yazısı çok güzel onlar yazma etkinliklerinde sıkılıyorlar, bazısının da okuması çok güzel okuma etkinliklerinde hemen okuyup bitiriyorlar.'ş̧eklinde yorumda bulunmuştur (Yapılandırılmamış Görüşme, Fatma, s:1-2, 09.05.2019).

Fatma öğretmene dil probleminin aşılmasında GEM'lerin nasıl bir rol üstlendiği sorulduğunda; ' 'GEM' ler Suriyeli öğrencilerin kendi dillerini unutmaması için oldukça iyi bir alan fakat Türkçeyi öğrenebilmeleri için çok faydalı değil maalesef. Öğrenciler sadece Türkçe derslerinde görüyorlar 
Türkçeyi. Teneffüste idarede Arapçaya devam ediyorlar'” cevabını vermiştir. (Görüşme, Fatma, s:1, 10.05.2019)

Dil problemini aşan öğrencilerin diğer öğrencilere oranla nelere dikkat ettiği sorulduğunda ise; ''En büyük farklılık merak. Öğrenci dili merak etmezse üç yıl da okula gelse öğrenemiyor. Sonra arkadaş çevresi; bazı öğrencilerin mahallede falan Türk arkadaşları oluyor onlar dile daha yatkın oluyorlar. Öğrencilerin ailelerinin Türkçeye verdiği değere göre de değişebiliyor. Öğrencinin dili önemsemesi gerek en başta bunun temeli de aile de atılıyor tabii. Öğrencilerin bazıları yurt dışına gitmeyi düşünüyor onlar çok hevessiz mesela.’’ cevabını vermiştir. (Görüşme, Fatma, s:3, 10.05.2019)

Mustafa öğretmen ise dil farkı ve tecrübe eksikliğinin kendisini çok zorladığını ifade etmiştir. (Görüşme, Mustafa, s:2, 02.05.2019) Derse girmeden önce hızlı konuştuğuna dikkat ettiğimiz öğretmen derse girdikten sonra konuşma hızını yavaşlatmış bir şekilde dersini anlatmaya başlamıştır.

Türkiye'ye alışmış ve dil problemini çözmüş öğrencilerin bunu nasıl başardığını sorulduğunda Mustafa öğretmen şu cevab1 vermiştir: 'Entegre olan öğrenciler ailesi tarafindan Türkiye'de kalınacağ 1 söylenen kişiler oluyor. Genelde olmayanlar da başka bir ülkeye gitme durumu olanlar oluyor.” (Görüşme, Mustafa, s:3, 02.05.2019).

Kendisi ile yaptığımız sohbetlerde Türkçe sınavlarından Kürt asıllı öğrencilerin daha başarılı olduğunu ifade eden Mustafa öğretmene o esnada öğretmenler odasındaki diğer öğretmenler de katıldıklarını söylediler. Arap öğrencilerin hem konuşmalarında hem de yazmalarında daha sıkıntılı olduklarını söyleyen öğretmenlerden bazıları Kürtçe biliyordu ve Kürtçenin Türkçeye çok da uzak bir dil olmadığını Arapçanın ise dil yapısı olarak da ortak kelimler noktasında da Kürtçeye göre daha uzak olduğunu düşündüklerini söylediler. (Gözlem, Mustafa, s:1-2, 01.05.2019).

Yaşadığ1 problemlerden bahseden öğretmen Emre öğretmen; en büyük zorluğun dil sorunu olduğunu şu örnekle belirtmiştir: "Veli geliyor mesela anlatamıyorsunuz çocuğunun durumunu illa ki tercüman gerekli oluyor."

Öğrencilerin dil seviyelerinin nelere bağlı olduğu konusunda ise; '’Yani öğrencilerin Türkiye’ye geliş tarihleri çok farklı kimi altı sene önce gelmiş kimi altı ay önce. Bu ikisinin dili aynı olmuyor ama sonradan gelen de diğerini yakalayamayacak diye bir şey yok. Her şey dili öğrenmek isteyip istememesine göre değişiyor. Komşularıyla iyi olan ailelerin çocukları hemen Türk arkadaş yapıp Türkçeyi daha hızlı öğrenebiliyor örneğin. Yaş da önemli bence küçük yaştaki çocuklar daha hızlı öğreniyor. Diğerleri kabulleniyor kimliklerini galiba. Bazısı Suriye’yi çok özlüyor, onlar Türkiye de rahat edemediğinden öğrenmek de istemiyorlar.(9)" cevabını vermiştir (Görüşme, Emre, s:2-3, 08.05.2019).

GEM' de çalışma esnasında ve genel anlamda Türkiye'de karşılaştığı en büyük soruna ilişkin Ayşe öğretmen de en büyük problemin dil olduğunu belirtmiştir: "Türkçeyi biraz biliyorum, biraz iletişim var. Türkiye’ye ilk geldiğimde Türkçeyi hiç öğrenemeyeceğimi düşündüm.’” cevabını veren 
öğretmen ilk geldiğinde genellikle İngilizce iletişim kurmaya çalıştığını ama Türkiye'de insanların sadece Türkçe konuşmayı istediğini dile getirdi. Suriyeli öğrencilerin Kuran-1 Kerimi unutmamaları için Arapça dilini öğrenmelerine devam etmelerini isteyen öğretmen, Türkçe kursunu daha üst seviye istediğini belirtmiştir.

Öğrencilerin Türkçeyi öğrenme hızındaki farklılıklara dair ise Ayşe öğretmen; ' Zekâ fark1 var, bakım, beslenme farkı var. Bazıları yeni hayatı kabul ediyor, bazıları kabul etmiyor. Bazılarının evde sıkıntı var; baba ve annelerinde sıkıntılar var. Hiçbir şeyleri yok ve çok sıkıntıları var. Yemek yok, evde eşyalar yok, akraba yok.'’ cevabını vermiştir (Görüşme, Ayşe, s:2-3, 16.05.2019).

Mehmet öğretmen de Türkiye'ye ve GEM'e alışabilmek için öncelikle dil sorununun çözülmesi gerektiği cevabını vermiştir (Görüşme, Mehmet, s:4, 20.05.2019). Ders esnasında Kürt öğrencileriyle iletişim problemi yaşadığını söyleyen öğretmen, bu durumu Arapça ve Kürtçe bilen öğrencilerin tercümanlığı sayesinde aşabilmekteydi. Öğretmen, dil sorununun sadece Türkçe-Arapça arasında olmadığını, Kürtçe-Arapça -Türkçe arasında olduğunu ifade etmiştir. Mehmet öğretmen konuşmamız esnasında verdiği bir örnekte, bazen Türk öğretmenlerin öğrencinin problemini anlamadıklarını ve sorunu Suriyeli idareciye taşıdıklarını söyledi. Suriyeli öğretmenlerin yardımcı olmaya çalıştıklarını fakat çocuğun Arapça da bilmemesi durumunda ne yapacaklarını şaşırdıklarını ifade etti (Görüşme, Mehmet, s:1, 17.05.2019).

Türkiye'de ve GEM' de karşılaşılan önemli problemin iletişim sorunu olduğunu söyleyen Zeynep öğretmen "Çocuklar Kürtler, Arapça ve Türkçe bilmiyorlar ben kendim de Türkçe bilmiyorum. Bu durumda iletişim sıkıntısı yaşıyorum." cevabını vermiştir. Dil problemini aşan ve aşamayan öğrenciler arasındaki temel fark sorulduğunda ise; "Aradaki fark çocuğun başarılı olup olmamasıyla alakalı. Ben nedenleri tam bilmiyorum daha yeniyim bu okulda. Mesela Sena'nın ailesi daha çok ilgi gösteriyordur, Ahmet'in ailesi ilgi göstermiyordur.'” cevabını vermiştir.

GEM' de çalışma esnasında ve genel anlamda Türkiye'de karşılaştığı en büyük soruna ilişkin Ali öğretmen; 'Zorlandığım noktalar; konuşma, kalabalık."'cevabını vermiştir. Dil sorununa ilişkin bir diğer cevabı ise; '’Ĕgitimde çok zorlanıyorum ders verdiğim öğrenciler Suriyeli ama Kürt oldukları için dediklerimi, beni anlamıyorlar. Dilimiz farklı.’’ şeklindedir. (Görüşme, Ali, s:2-3, 14.05.2019).

Ali öğretmen ile konuşmalarımızda diğer tüm Suriyeli öğretmenlerin aynı durumlardan yakındıklarını söylediğimizde, göç eden kesimin Suriye'de Kürtlerin ağırlıklı olarak yaşadığı bölgeden gerçekleştiğini bu sebeple de aynı sıkıntıları yaşadıklarını söyledi. Öğretmen Türkler göç edip gelmiş herkese Suriyeli diyip Arapça konuştuklarını sandıklarını fakat kendi aralarında dil sıkıntılarının olduğunu dile getirdi. Bunların başında Kürtçe Arapça arasındaki dil farkı ikincisi ise Arapçanın yöresel farklarından kaynaklıymış. Mesela Şam'dan gelmiş bir öğrenciyle Halep'ten gelmiş bir öğrenci aynı Arapçayı konuşmuyorlarmış, birbirlerini anlasalar bile aynı dil değilmiş. 
Dil problemini aşan ve aşamayan öğrenciler arasındaki farkı ise şu şekilde açıklamıştır; "Birinci fark zekâ, ikinci fark aile. Kardeşim Türkçeyi çok iyi biliyor. Öğretmeni her hafta her hafta geldi özel ders verdi. Şimdi her yerde tercümanlık yapabiliyor" (Görüşme, Ali, s:2-3, 14.05.2019).

\section{Uyum}

Bu bölümde Türk ve Suriyeli öğretmenlerin çok kültürlü ve çok dilli GEM ortamında birbirlerinden hangi noktalarda etkilendiklerine ve uyuşmazlıklara ne gibi çözümler ürettiklerine ve birbirlerinde benzer, farklı gördükleri noktalara dair bulgulara yer verilmiştir.

Suriyelilerle ilk defa geçici eğitim merkezinde öğretmenlik yapmaya başladığında karşılaştığını ifade eden ve Suriyeli öğretmenlerle oldukça samimi olduğu gözlemlenen Melek öğretmen, GEM' de çalışmaya başladıktan sonra hayatında ve öğretmenlik mesleğini geliştirmede önemli değişiklikler yaşadığını belirtmiştir: “Örneğin Arapça dilini artık anlayabiliyorum. Arapça dilini anlamam da öğrencileri anlamama katkı sağladı. Suriyeli öğrencilerle evet tabi ki problemler var. Ama ben gayet memnunum hatta gelecekte de bu işi yapmaktan keyif alacağımı düşünüyorum. Çünkü mesela Araplarla ya da yabancılarla çalıştığımda kendimi de kültürel anlamda geliştiriyorum. Suriyeliler ve diğer başka hiçbir ırk hakkında kötü fikirlere sahip değildim. Nötr durumdaydım. Fakat Suriyeli öğrencilerle çalışmaya başladığımda onları sevmeye başladım. Onlara Türkleri ve Türkçeyi sevdirmek için uğraşıyorum"' (Görüşme, Melek, s:1-2, 06.05.2019).

Fatma öğretmen ise; 'Benim Suriyelilere dair algıda seçiciliğim oluştu. Okul içindeki sorumluluğum sanki okul dışına da yansıdı. Sosyal hayatta da hemen yardımcı olmaya çalışıyorum. Ekstradan Arapçaya kulak aşinalığım oluştu. Tam olarak anlamasam da konuşmaların bir kısmını anlayabiliyorum. Suriye'deki kültürü öğrendik sonra çok benziyoruz desek de farklılıklar da oldukça fazla" yorumunda bulunmuştur (Görüşme, Fatma, s:1, 10.05.2019).

GEM' de çalışmaya başlamadan önceki ve sonraki düşüncelerine dair fark1 ise şu şekilde ifade etmiştir: "Suriyeliler hakkında ne olumlu ne olumsuz hiçbir şey düşünmüyormuşum onu fark ediyorum. Çünkü bu kadar yoğun oldukları bir yerde yaşamıyordum. GEM'de çalışmaya başladıktan sonra da dediğim gibi pozitif yönde seçicilik başladı. Önceden zor bir durumda kaldıklarında üstüme alınmazdım, şimdi direkt sorumlu hissedip sorunu çözmeye çalışıyorum. Dil bilmeden de sorunları çözmeye alıştık galiba.' (Görüşme, Fatma, s:1, 10.05.2019). "GEM' de çalışmaya başladığımda sanki ben Suriye'ye gitmişim gibi hissetmiştim. Binada Türkçe konuşan bir müdürümüz bir de öğretmen arkadaşlarımız var. Ama yavaş yavaş alışıyor insan, diyalog kurdukça aslında sadece dillerin farklı olduğunu gördüm. Zorlandığım noktalar bunlar oldu ve zaman geçtikçe düzeldi şükür. Zorlanmadığım noktalar ise aynı dini paylaşıyor olmamızdan doğan kültürel benzerlikler tabii. Sonra öğrenciler oldukça saygılılar, Türkiye'yi ve bizi çok merak ediyorlar.' diyerek anlatmıştır. (Görüşme, Fatma, $\mathrm{s}: 2,10.05 .2019)$ 
Mustafa öğretmen GEM' de çalışmaya başlamadan öncesine dair ''Suriyeliler hakkında olumsuz düşüncelerim yoktu. Ve zaten öğrenci yaştaki çocukların bana olumsuz bir düşünce vermesi söz konusu olamaz ''cevabını vermiştir. Düşündüğünden daha farklı bulduğu noktalara örnek olarak ise; '’Din konusunda daha hassas olduklarını düşünüyordum öyle değilmiş.' demiştir( Görüşme, Mustafa, s:1, 02.05.2019)

Her sohbetimizde sık sık kafasındaki Suriyeli algısıyla gördüklerini ilişkilendiremediğini dile getiren Mustafa öğretmen henüz yetişkinlere dair kültürel uyumunu gerçekleştirebilmiş gibi görünmüyordu. Öğrencilerine oldukça yakın ve samimi davranan öğretmen öğrencilerinin beslenmelerinde getirdiği Suriye'ye özgü bir baharatla yapılan dürümden tattığını söyledi. Kendisinin damak tadına çok uymadığını ama öğrencilerinin bu yiyeceği çok sevdiğini söyleyen Mustafa öğretmen; "pencereleri açıp sınıfı havalandırmaları karşılığında sınıfta yemelerine izin veriyorum." dedi (Yapılandırılmamış Görüşme, Mustafa, s:1-2, 01.05.2019).

GEM' de çalışmanın okul dışındaki yaşantısına örnek olarak Emre öğretmen; '’Ben de pek bir farklılık olmadı aslında, sadece çevremde Suriyeliler ile kodlanmış durumdayım. Farkındalık oluştu denilebilir belki öncesinde hiç kulak asmadığım Suriye haberlerine şimdi daha duyarlıyım. Örneğin önceden savaşın bitişi, nedenleriyle falan çok ilgili değildim şimdi iç savaş hakkında epey bilgiye sahibim.' cevabını vermiştir.

Yoğun olarak Suriyelilerin bulunduğu eğitim ortamına alışma süreci hakkındaki görüşleri ise şu şekilde;'’Ben hemen alıştım ya problem olmadı. Önceki okulumda kız öğrenciler vardı hep onlar çok çekiniyorlardı bu durumda ben de sınıfta geriliyordum. Cinsiyet kavramı çok erken de otursa sonuçta çocuklar ve zamanla alışıyorlar. Yani aslında onlar bana entegre oldu ben onlara değil. Zorlanılan en büyük sıkıntı dil tabii. Ama kültür noktasında, öğretmene duyulan saygı noktasında hiç sıkıntı yaşamadım ben o noktada çok saygılılar." (Görüşme, Emre, s:2-3, 08.05.2019).

Ders aralarındaki sohbetlerimizde Emre öğretmen daha önceki okulundaki Suriyeli öğretmenlerle Suriye'nin meşhur yemeği olan felafel yemeğe gittiklerini ve yemeği çok beğendiğini söyledi. Diğer öğretmenlerinde bu yemeği merak etmeleri üzerine bir gün hep birlikte felafel yemeğe gitmeye karar verdiklerini ifade etti. (Yapılandırılmamış Görüşme, Emre, s:1, 07.05.2019).

Türkiye'ye ilk geldiğinde çok şaşırdığını söyleyen Ayşe öğretmen; 'Önce çok zordu, metrobüslerden çok korktum çok kalabalıktı, yollar çok uzun, binalar çok büyüktü. Suriye'de en fazla 10 kat var yani. Türkiye'ye alıştım, Suriye'de yaşamak çok zor; su yok. Suriye'de savaş bitince sıkıntılar kalıyor, Suriye belki 20 sene istiyor. Burada işim var, evim var. Suriye'de evimi kaybettim, irtibat kalmadı.(13)' "şeklinde deneyimleri ve geleceği hakkında yorum yapmıştır (Görüşme, Ayşe, s:3, 16.05.2019).

Mehmet öğretmen ise uyum süreci hakkında şu görüşlerini paylaşmıştır: "Hayat Suriye'ye göre Türkiye'de çok zor. Mesela terzilikte çalışma saati 12 saat ama maaş çok az, bu bölge çok pahalı. 
Sonra öğretmenlik yapmaya başladım daha iyi yani. Türkiye'ye ilk geldiğimde pişman oldum ama sonra alıştım. Hayat durumu zor, Suriye'den her şey sıfır geldim. Suriye'de öğretmenlere çocuklar çok saygıl1, Suriye'de öğretmenlikte çok fitne var ama burası değil. Burada daha muhabbet var. Burada akrabalarım var. Müslüman bir belde ve Suriye'ye yakın. Savaş bittikten sonra hemen Suriye'ye gideceğiz. Burası oldukça pahalı, ev çok para. Suriye memleket akrabalar orada. Ev orada." (Görüşme, Mehmet, s:2-3, 20.05.2019).

TRT'de çalışmasının kendisini daha da özgüvenli hissettirdiğini gözlemlediğimiz öğretmen, konuşmalarımızda ekstra işlerinin kendisini maddi yönden oldukça rahatlattığını söyledi. Özellikle okuldan arta kalan vakitlerinde tercümanlık yaptığını ifade etti (Yapılandırılmamış Görüşme, Mehmet, $\mathrm{s}: 1,17.05 .2019)$.

Türkiye'ye geldiğinde karşılaştığı sorunları ve alışma sürecini Zeynep öğretmen şu şeklide ifade etti: “Türkiye'ye ilk geldiğimde çok zorlandım ama komşularım, arkadaşlarım bana yardımcı oldular. Türkiye'ye birkaç ay sonra alıştım, komşularım yardımcı oldular, kolaylıkla alıştım. Komşularımdan bazıları Mardinli, Arapçaları var ayrıca kızlarımın da Türkçeleri iyi bu şekilde anlaşıyoruz. Adetler, din ve yiyecekler konusunda çok yakınız" (Görüşme, Zeynep, s:1, 22.05.2019).

Türkiye de işlerin çok yavaş ilerlediğini söyleyen Ali öğretmen Türkiye'ye alışma süreci hakkında; " Türk insanları çok yardımcı oldular baştan. Havalimanından komşularım aldılar. Zorlandığım noktalar; konuşma, kalabalık. Evim kira, ortalama bir kira ama Suriye'de kendi evim vardı daha rahattım. İş güzel sıkıntı yok.” Cevabını vermiştir (Görüşme, Ali, s:1, 14.05.2019). Savaş bittikten sonrası için ise; "Suriye'ye gideceğim ama her zaman Türkiye'ye ziyarete geleceğim. Sebebi; ben Türküm artık, vatandaşlığımı aldım. Buranın vatandaşıyım ama illaki memleket gibi olmaz. Suriye de çok güzel ülke.’ cevabını vermiştir (Görüşme, Ali, s:4, 14.05.2019).

Suriyeli öğretmenlerde genel anlamda dikkatimizi çeken nokta aslında Suriye'de daha rahat yaşıyorken Türkiye'ye gelip sıfırdan başlamanın kendilerinde bıraktığı şok duygusuydu. Konuşmalarımızda sürekli Suriye'yi özlediklerinden, Suriye'nin kesinlikle Türkiye kadar pahalı olmadığından bahsediyorlardı. (Gözlem, Ali, s:1, 13.05.2019).

\section{GEM' lerde Karşılaşılan Eksiklikler Ve Yasal Sıkıntılar}

Bu bölümde Türk ve Suriyeli öğreticilerimizin GEM' de eğitim verirken karşılaştıkları temel eksikliklere, yasal sıkıntı ve beklentilerine dair verilere yer verilmiştir.

Geçici eğitim merkezlerindeki eğitim ve öğretim faaliyetlerinde karşılaştığı eksikliklere dair Türkçe öğreticisi Melek öğretmen; ' 'GEM' de materyal eksikliği yaşıyoruz. Gerek projeksiyon, gerek bilgisayar, kitap vs. bu konularda destek yetersiz. Aileler ilgisi çocuklarının sorunları ile ilgilenmiyor. Veli toplantılarına dahi katılım yok denecek kadar az." cevabını vermiştir (Görüşme, Melek, s:2, 06.05.2019). 
Öğretmenler odasındaki konuşmalarda ailelerin ilgisizliğinden genel anlamda şikâyet eden öğretmenlerimizin en çok şikâyet ettiği diğer konular da doğru iletişim numarası veya adrese sahip olamamalarıdır. Konuşma esnasında Melek öğretmen; "Hocam numarayı arıyoruz ulaşılamıyor, veli ziyareti yapalım diyoruz adreste başkası oturuyor." şeklinde yorumda bulunmuştur (Yapılandırılmamış Görüşme, Melek, s:1-2, 03.05.2019).

Eksikliklere ve sıkıntılara dair Fatma öğretmen ise; "En büyük problem materyal gibi görünüyor. Çünkü dil öğretiyoruz ve normal bir dersten daha çok görsel ve materyal desteği istiyor. Yetkililer materyal ve çalışma şartları noktasında daha yardımcı olabilirler. Mesela tatilimiz çok az ve bu da bizim çalışma performansımızı etkiliyor. Öğrenciler de aynı şekilde hiç dinlenmiyorlar neredeyse. Aileler eğitim noktasında biraz geri düşünüyorlar, veli toplantılarına katılım çok az oluyor mesela." cevabını vermiştir (Görüşme, Fatma, s:2, 10.05.2019)

GEM'de karşılaşılan eksikliklere dair öğretici Mustafa öğretmen; ' GEM' lerde eğitimin programsız olması işleri çok zorlaştırıyor. Ne yapılacağı hakkında fikirsiz kaldığım zamanlar oluyor. Materyal eksiğimiz var, biten ya da bozulan materyallerin tekrar kullanılması çok zaman alıyor.Mesela okulumuzda akıllı tahta var ama çalışmıyor. Sadece iki tane projeksiyonumuz var, her istediğimiz zaman kullanamıyoruz. Ve her ders projeksiyonun kurulması ve kullanılması zor oluyor." şeklinde cevap vermiştir. (Görüşme, Mustafa, s:2, 02.05.2019)

Geçici eğitim merkezlerindeki eksikliklere dair Emre öğretmen'in cevabı şu şekildedir; 'Bizim en büyük sıkıntımız dinlenememek, tatillerimiz biraz daha fazla olabilir. Bir kadro kaygımız var, inşallah emeklerimizi değerlendireceklerini düşünüyorum ben. Sınıf içerisinde ise sıkıntı akıllı tahtalar, projeksiyon aleti gibi materyaller. Dil öğretmek diğer alanlara göre daha zor. Bulut kelimesinin Arapçasını bilmiyorsanız öğrenciye anlatamıyorsunuz, illa ki resim gerekli oluyor."

Yasal sıkıntıları hakkında ise ; 'Bu meslekte önümüzü göremiyoruz, evleneceğim mesela daha net şartlara ihtiyacım var. Örneğin; bizim projede yer değişikliği çok oluyor, burası da kapanabilir mesela, bekârken problem olmuyordu ama evlenince problem olur." şeklinde yanıt vermiştir." (Görüşme, Emre, s:2-3, 08.05.2019).

Öğretmenlerle konuşmalarımızın çoğunda kadro isteklerini dile getirmeleri ilk günden itibaren epey dikkatimizi çekmişti. Çalışırken KPSS ye hazırlanmanın epey zor olduğundan ve bu işte epey tecrübe sahibi olmalarından dolayı kendilerini araya sıkışmış gibi hissediyorlardı. Sürekli yer ve okul değiştirmenin ekonomilerine çok zarar verdiğinden ve maaşların belli bir gününün olmamasından da oldukça rahatsızlardı.

Öğretmenlerin materyal konusunda kendi aralarında sürekli yardımlaşmada bulunduklarını, hazırladıkları bir etkinliğin bir kopyasını hemen öğretmenler masasına bıraktıklarını gözlemledik. Konu paralelliğini çok sağlayamadıklarını ama yine de bu tarz paylaşımların çoğu şeyi hallettiğini söylediler. (Yapılandırılmamış Görüşme, Emre, s:1, 07.05.2019). 
Suriyeli gönüllü öğretici Ayşe öğretmen; ' Akı1lı tahta burada var ama Suriye'de yok, yardımcı araçlar Suriye'de çok var ama burada yok. Kitaplar geç geliyor burada. Burada disiplin daha iyi. Bu okul daha büyük temiz ve daha rahat. Tahtalar, sıralar, sandalyeler daha iyi. Kütüphane okulumda çok iyiydi, çok fayda var. Burada yok mesela. Sınıflar çok kalabalık, kitaplar geç geliyor." şeklinde Suriye ve Türkiye'yi karşılaştıran bir cevap vermiştir. Yasal hakları noktasında ise; Suriye'de emeklilik vardı, maaş vardı ama Türkiye'ye geldik yok.'”cevabını vermiştir (Görüşme, Ayşe, s:2-3, 16.05.2019).

Geçici eğitim merkezinde karşılaştıkları sıkıntılar ve eksiklikler hakkında Suriyeli gönüllü öğretici Mehmet öğretmen; "Suriye'de çocuklar önemli ama bu kadar rahat değil yani. Türkiye'de çok şımarıklar. Suriye'de şiddet değil ama biraz korku var. Mesela çocuklara kitap çok geç geldi. Bu sene çok fazla Kürt çocuk geldi, Arapça bilmiyorlar ve bu durum biraz zor. Çocuklar için kitap gerekiyor. Çocuklar 2009'lu ama küçük sınıfa geliyorlar bunlarda eğitim yok ama sınıfa koyuluyorlar, sıkıntı yani. Türkiye hükümeti Suriyeliler için çok yatırım yaptı ama ben almadım yani ulaşmadı. Çocuklar Türkçe biliyor, tercümanlık ediyor ama okuma yazması yok mesela, çok bilmiyorlar. " cevabını vermiştir.

Yasal sıkıntıları hakkında ise maaşının daha yüksek olmasını istediğini söylemiştir. (Görüşme, Mehmet, s:2-3, 20.05.2019). Öğretmen ile ders arası sohbetlerimizde Türkiye'nin oldukça pahalı bir ülke olduğundan ve geçimini zor sağladığından bahsetti. Ailecek başka bir şehre göç etmeyi düşündüklerini fakat bu seferde orada iş imkânları noktasında sıkıntı yaşamaktan korktuğuna değindi (Gözlem, Mehmet, s:1, 17.05.2019).

GEM hakkındaki eksiklikler hakkında Zeynep öğretmen; "Çocuklar uzun zamandır derslerden kopuk bir şekildeler, hiçbir fikirleri yok ders, okuma hakkında. Mesela dördüncü sınıf ama hala harfleri bilmeyen çocuklar var... Ailelerden oluşan sıkıntılar var; çocukların üzerinde çok durmuyorlar, çocuklar bir geliyor bir gelmiyorlar, devamsızlıkları fazla. Çocukları sınıflarda daha özgür görüyorum Suriye’ye oranla. Araçlar(akıllı tahta) burada daha yeterli, Suriye'de daha zayıf. Diğer okulumuzda her şey çok iyiydi, düzen çok iyiydi araçlar yeterliydi ama burada bazen tahta kalemi bile bulamıyorum, kitap da yok. Çocuklar da çok farklı. Aynı şeyler; kitap, devamsızlık ve dil sıkıntısı (Çocuklar Kürt ben Arabım). Gelecek senenin daha iyi olmasını temenni ediyorum. Kitapları temin etmelerini gerçekten istiyorum, materyallerin olmasını istiyorum.” cevabını vermiştir (Görüşme, Zeynep, s:1, 22.05.2019).

Yasal hakları hakkında ise; "Işsimiz devamlı olsun istiyorum ve İmam Hatiplerde Arapça derslerini biz verelim istiyorum. Geleceğim hakkında hiçbir şey bilmiyorum. Öğretmenlik dışında başka bir işte çalışamam.’’ şeklinde yanıt vermiştir. (Görüşme, Zeynep, s:2-3, 22.05.2019).

Geçici eğitim merkezindeki eksiklere dair Suriyeli gönüllü öğretici Ali öğretmen ise şu görüşü paylaşt1: "Doğruyu söylemek gerekirse çok yetersiz. Konuşmak çok güzel, ortam güzel ama araçlar çok yetersiz. Ağacı anlatacağım ama bir materyal yok, tahta biraz da olsa yardımcı oluyor. Kendi 
adıma söylemek gerekirse araçların olup olmaması benim için hiçbir şey değiştirmez ben her şekilde girer dersimi anlatırım. Eğitimde çok zorlanıyorum ders verdiğim öğrenciler Suriyeli ama Kürt oldukları için dediklerimi, beni anlamıyorlar. Dilimiz farklı. İkinci sıkıntı, öğrencilerin annesi işte babası işte, öğrenci rahat(disiplinsiz). Suriye'de öğrenci iyiydi ama savaş var, şimdi anne işte baba işte zararlı öğrenci. Türkiye'de şimdi kitap yok, heykeller yok. Hayat bilgisinde ihtiyaç çok var ama burada yok Suriye'de çok var çünkü bizim vatan, bizim kitap, bizim dil her şey var.'” (Görüşme, Ali, $\mathrm{s}: 2-3,14.05 .2019)$.

Yasal hakları ve beklentileri hakkında ise; "Çalıştığımız işte kalıcı olmayı istiyorum. Öğretmen kimliği istiyorum. Maaş çok az, yavaş yavaş fazlalaşsa daha iyi olur. (Görüşme, Ali, s:3, 14.05.2019) şeklinde görüş bildirmiştir.

Geçici Eğitim Merkezinde en önemli problem merkezin bir plazanın ara katında bulunuyor olmasıydı. Öğrenciler bir okul atmosferinden epey uzaktaydılar. Enerjilerini atabilecekleri bir okul bahçesi yoktu. Teneffüs olduğunda koridorlar çok kalabalık oluyordu. Türk öğretmenler ve Suriyeli öğretmenlerin öğretmenler odası farklıydı, bu durumun öğretmenlerin birbirlerine karşı uyumunu geciktirebileceği açıkta ortadaydı (Gözlem, Ali, s:1, 13.05.2019).

\section{Mesleki Deneyim ve Eğitim Eksikliği}

$\mathrm{Bu}$ bölümde öğretmenlerin geçici eğitim merkezlerinde eğitim verebilecek kadar eğitim ve tecrübeye sahip olup olmadıklarına, aldıkları eğitimlerin çalışma hayatlarına ne derece faydalı olduğuna dair bulgulara yer verilmiştir.

Öğretmenlerle sohbetimizde öğretmenlerin bu işe yönelik iki kere eğitim aldıklarını öğrendik. Birincisi işe henüz başlamadan Antalya, Afyon gibi illerde verilen eğitim; ikincisi ise işe başladıktan sonra bir devlet üniversitesi bünyesinde Milli Eğitim Bakanlı̆̆ tarafından verilen Yabancılara Türkçe Öğretimi sertifika programıymış. Öğretmenlerin kendi aralarındaki konuşmalarından dil öğretimi noktasında çok fazla tecrübeli olmadıkları anlaşılıyordu. Sürekli birbirlerine 'Fiilleri nasıl öğretiyorsun, noktalama işaretlerini şimdi versem anlarlar mı?', tarzında sorular soruyorlardı. Aldığ eğitimleri sorduğumuzda Melek öğretmen; "Antalya'da bu konuda bir seminer almıştık. Seminerin hiçbir faydası olmadı. Bence bu iş için teori değil, sahada eğitim olmalı. Evet, bunun eğitimini İstanbul üniversitesinde almıştım. Eğitimi gayet başarılı buldum. '” şeklinde cevap vermiştir.

Tecrübelerini nasıl kazandığını sorduğumuzda ise; '’Ben de bu işin tecrübesini sahada yani okulumuzda kazandım. Kendimi yeterli hissediyorum, farklı etkinliklerle derslerimi pekiştiriyorum.(7)" şeklinde cevap vermiştir. (Görüşme, Melek, s:2-3, 06.05.2019).

Tecrübelerine dair ileriye yönelik fikirlerini konuştuğumuz öğretmenin en çok istediği şeylerden birinin, bu işte tecrübe kazanmış Türkçe öğreticisi arkadaşlarıyla birlikte bir Türkçe öğretim seti hazırlamak ve yapabilirse lisansüstü eğitimi almak olduğunu ifade etti. (Yapılandırılmamış Görüşme, Melek, s:1-2, 03.05.2019). 
Proje kapsamında aldığı eğitimler hakkında Fatma öğretmen ise şu bilgiyi paylaşmıştır: "Projenin başında 15 gün bir eğitim almıştık. Sonrasında ise İstanbul üniversitesinde Türkçe öğretimi sertifikası aldık. İstanbul üniversitesindeki eğitim daha faydalı oldu, hocalarımız sahada çalışmış insanlardı. Yeterli hissetmek için etkinlik oluşturdum sürekli.” (Görüşme, Fatma, s:2, 10.05.2019)

Daha önce hiç öğretmenlik tecrübesi olamayan Fatma öğretmen;’’ Türk öğrencilerle hiç çalışma fırsatım olmadı aslında ama bu işte tecrübe kazandığım için bu işte daha başarılıymışım gibi geliyor. Tecrübeler aldığımız eğitimin önüne geçebiliyor, normalde sınıf öğretmeniyim ama şuan sınıf öğretmenliği daha zor görünüyor bana." şeklinde cevap vermiştir.

Diğer arkadaşlarının tecrübelerinden faydalanmak ve kendi tecrübelerini pekiştirmek adına ise;'’Sosyal medyada diğer arkadaşlarla tecrübelerimizi paylaştığımız alanların da faydası var. Ben şahsım adına Türkçe öğretimi için hangi kaynaklar kullanılıyorsa hepsini edindim açıkçası.' cevabını vermiştir. (Görüşme, Fatma, s:2, 10.05.2019)

Mustafa öğretmen projede çalışmaya başladığında önce dil farkı ve tecrübe eksikliğinin kendisini çok zorladığını (6) söylemiştir. Daha sonrasında kendisini geliştirmek ve yeterli hissetmek için TÖMER kursu ve Eğitim kursu aldığını, makaleler okuyup videolar izlediğini söylemiştir.

Emre öğretmene ilk başladığında tecrübe eksikliğini nasıl aştığını sorduğumuzda "Ben hep video izledim bir de anlatacağım konunun ana kelimelerini Arapça öğrendim. Yarım saat kelimeyi anlatmaya çalışmaktansa küçük küçük Arapça noktalara değiniyordum hemen anlıyorlardı. Hem zamandan da tasarruf etmiş oluyordum." cevabını vermiştir.

Projeye ve Türkçe öğretimine dayalı aldıkları eğitimi sorduğumuzda ise" Projeye başlamadan önce 15 gün eğitim almıştık ama hep teoriydi o, sonrasında İstanbul üniversitesinde aldığımız eğitim daha çok faydalı oldu. Yurtdışında falan Türkçe öğretmiş hocalarımız gelmişlerdi. '’ cevabını vermiştir.

Geçici eğitim merkezinde çalışmaya başlamadan veya başladıktan sonra herhangi bir eğitim alıp almadıklarını ve lisansüstü eğitim almak isteyip istemediklerini sorduğumuz Suriyeli gönüllü öğreticilerimizin cevapları şu şekilde olmuştur:

Ayşe öğretmen ''Hizmet içi eğitim Türkiye'de almadım. Lisansüstü eğitim düşünüyorum ama çalışırken zor. Burada önce para lazım.' (Görüşme, Ayşe, s:4, 16.05.2019).

Mehmet öğretmen;'” Türkiye'de hiç almadım. Lisansüstü eğitim düşünüyorum inşallah, işler biraz düzelsin.' (Görüşme, Mehmet, s:4, 20.05.2019).

Zeynep öğretmen; ' 'Öyle bir eğitim almadım. Lisansüstü eğitim imkânım olsa çok isterim. Ama Türkiye'de nasıl yapıllyor hiç bilmiyorum. Hiçbir bilgim yoktu, şimdi güzel düşünüyorum." (Görüşme, Zeynep, s:4, 22.05.2019). 
Ali öğretmen; " Hayır, almadık. Ben başvurdum sonra kabul edildim, başladım. Lisansüstü eğitim ilk geldiğimde düşündüm ama çalışmak lazım. Sonra inşallah başlayacağım.’' (Görüşme, Ali, $\mathrm{s}: 4,14.05 .2019)$.

\section{TARTIŞMA, SONUÇ VE ÖNERILER}

$\mathrm{Bu}$ araştırma geçici eğitim merkezlerindeki öğretmenlerin tecrübelerinden faydalandığı için geçici eğitim merkezlerinin eksiklerini tespit etmek ve işleyişlerini daha sorunsuz bir hale getirebilmek için oldukça önemlidir.

Araştırmada edinilen sonuçların alandaki diğer araştırmaların sonuçlarıyla tekrardan değerlendirilmesi araştırmanın diğer araştırmalarla hangi noktalarda benzer veya farklı sonuçlara vardığını tespit etmek için oldukça önemlidir.

\section{Geçici Eğitim Merkezinde Öğretmen Olmak}

Öğretmenlerin görüşme ve gözlem verilerine göre geçici eğitim merkezlerinin öğrencilerin Arapçayı unutmamaları açısından faydalı olduğu fakat Türkçeyi öğrenmeleri adına çok işlevsel olamadığı sonucuna varılmıştır.

Verilere göre öğretmenler geçici eğitim merkezinde öğretmen olmayı farklı, ders anlatımı noktasında zor ve çok dilli bir ortam olması açısından ise oldukça güzel bir tecrübe olarak tanımlamışlar ve öğrencilere Türkçe öğretirken öğretmenlik anlayışlarına ve tecrübelerine yeni bakış açıları kattıkları tespit edilmiştir.

Öğretmenler geçici eğitim merkezinde çalıştıkları süre boyunca daha anlaşılır bir şekilde konuşmaya başladıkları ve konuları öğrencilerinin tam anlayabilmesi için en sade şekilde anlattıkları sonucuna varılmıştır.

Geçici eğitim merkezinde çoğunluğun Arapça konuşuyor olması ve öğrencilerin Türkçe öğretmenleri dışında Türkçeyi kimseyle konuşmamalarının öğrencilerin Türk eğitim sistemine entegrasyonunu olumsuz etkilediği ve Türkçeyi öğrenmelerini geciktirdiği sonucuna varılmıştır. Boylu ve Işık (2019) da araştırmalarında öğrencilerin etraflarındaki insanların Arapça konuşmasının öğrencilerin yeni bir dil öğrenme süreçlerini olumsuz etkilediğini tespit etmiştir.

Proje kapsamında uzun yıllar çalışan ve birçok okul değiştiren öğretmenlerin dil öğretiminde daha tecrübeli ve disiplinli olduğu ve bu durumun öğrencilerin dil öğretimine verdiği önemi olumlu anlamda etkilediği sonucuna varılmıştır.

Öğrencilerin Suriye'deyken etnik kimlik ve yaşadıkları bölgelere göre ayrıldıkları fakat Türkiye'ye geldiklerinde eşit eğitim şartları verildiği ve bu durumdan Suriyeli öğretmenlerin memnun olduğu sonucuna varılmıştır. 
Suriyeli öğretmenlerin geçici eğitim merkezinde çalışmayı hem iş, maaş ve çalışma saatlerinin az olması hem Türk arkadaşlarıyla sosyalleşme ve Türkiye’ye, Türk kültürüne entegrasyonları açısından oldukça faydalı buldukları sonucuna varılmıştır.

Veriler doğrultusunda geçici eğitim merkezindeki öğretmenlerin, savaş ve göçün öğrencilerin psikolojilerini olumsuz etkilediğini düşündükleri ve aile fertlerini kaybetmiş veya ekonomik sıkıntı yaşayan öğrencilerine psikolojik vb. noktalarda yardımcı olmaya çalıştıkları tespit edilmiştir.

Mehmet Emin Usta'nın araştırmasında Suriyeli öğretmenler kendilerinin ve öğrencilerin psikososyal yardım almalarının gerektiğini savunmuşlardır. Öğretmenler içlerinde bulundukları ortam ve savaşın kendilerinde psikolojik sorunlar doğurduğunu belirtmiştir (Usta ve Arıkan, 2018). Boylu ve Işık (2019) da Öğrencilerin sınıftaki davranışlarında agresif tavırlar sergiledikleri ve teneffüslerde savaş ve silah temalı oyunlar oynadıklarını tespit etmiştir. Usta, Arıkan, Şahin ve Çetin (2018) in araştırmasına katılan Suriyeli öğretmenler de kendilerinin ve öğrencilerin psikolojik yardım almaları gerektiğini savunmuşlardır. Sönmez (2019) öğrencilerin savaş sonrası ortaya çıkan psikolojik bozukluklarının eğitimi olumsuz yönde etkilediği sonucuna varmıştır. Yapıcı (2019) da öğrencilerin öncelikli olarak psikolojik yardıma ihtiyaçlarının olduğunu belirtmiştir. Keskinkılıç Kara ve Şentürk Tüysüzler (2017) öğrencilerin öncelikle saldırganlık, içe kapanıklık gibi davranışlarının ortadan kaldırılması için geçici eğitim merkezlerinde öncelikli olarak psikolojik yardımda bulunması gerektiğini belirtmiştir. Suriyeli öğrencilerin yeterli psikolojik yardımı alamamaları öğrencilerde travma sonrası stres bozukluğu ve depresyon gibi psikolojik birçok soruna neden olmaktadır (UNICEF-Gap Çalıştay Raporu,2016).

\section{Dil ve Uyum}

Yapılan araştırmada geçici eğitim merkezindeki Suriyeli ve Türk öğretmenleri eğitim sürecinde en çok dil probleminin zorladığı sonucuna varılmıştır. Mehmet Emin Usta (2018) da araştırmasında Suriyeli öğretmenlerin geçici eğitim merkezlerinde karşılaştıkları en büyük sorunun dil problemi olduğunu tespit etmiştir. Moralı (2018) araştırmasında öreticilerin zorlandığı en büyük problemlerden birinin dil sorunu olduğu sonucuna varmıştır. Keskinkılıç Kara ve Şentürk Tüysüzler (2017) de araştırmasında öğrencilerin zorlandığı en büyük sorunların dil ve uyumdan kaynaklandığını vurgulamıştır.

Türk öğretmenler öğrencilerin Türkçe bilmemelerinde sorun yaşarken Suriyeli öğretmenler göre ise problem öğrencilerin ana dillerinin Kürtçe olması ve Arapça ve Türkçe konuşamamalarından kaynaklanmaktadır.

Türk öğretmenlere göre dil probleminin aşılamamasının en büyük nedeninin öğrencilerin okul içinde ve dışında sürekli Arapça konuşuyor olmaları ve Türkçe dersi dışındaki diğer tüm dersleri Arapça görmeleridir. Keskinkılıç Kara ve Şentürk Tüysüzler (2017) de araştırmalarında öğrencilerin 
devlet okullarında Türkçeye daha fazla maruz kalmalarından dolayı sorunlarını daha hızlı bir şekilde çözebildiklerini belirtmiştir.

Öğretmenlerin görüşlerine göre geçici eğitim merkezinde öğrencilerin idare dâhil olmak üzere sürekli Arapça konuşmaları Türkçe başarılı düşürmekte ve öğrencinin de Türkçeye dair öğrenme isteğini en aza indirdiği sonucuna varılmıştır. Öğretmenler sorunu çözmeye yönelik öğrencilerin Türkçe dersi içerisinde Arapça konuşmalarını yasaklamak gibi çözümler ürettiklerine ulaşılmıştır.

Türk öğretmenler geçici eğitim merkezinde yoğun olarak Arapça konuşulmasının Türkçe öğretimine zarar verdiğini düşünseler de Suriyeli öğretmenler öğrencilerin Arapçayı özellikle Kuran-1 Kerim okuyabilmeleri için gerekli görmektedirler. Mehmet Emin Usta (2018) araştırmasında Suriyeli öğretmenlerin her ne kadar öğrencilerin Türkçeyi öğrenmelerini isteseler de Arapçayı da unutmamaları gerektiğini düşündüklerini belirtmiştir. Kaya (2019) Suriyeli öğretmenlerle gerçekleştirdiği görüşmelerin sonucunda öğretmenlerin, öğrencilerin Arapça eğitimine ayrı bir özen gösterilmesinin gerektiğini savunduklarını belirtmiştir.

Öğretmenler ailelerle yaşadıkları dil problemini tercüman yardımıyla çözmeye çalışmaktadır. Yaşanılan bu tarz dil sorunları Türkçe öğretmenlerini Arapçaya yönlendirmiş ve Arapçayı kendilerinde bir eksik olarak görmeye başladıkları sonucuna varılmıştır.

Suriyeli öğretmenler, Türk öğretmenlerin karşılaştıkları dil probleminin benzerini Arapça bilmeyen Kürt ailelerle yaşamaktadır ve Arapça bilmeyen Kürt çocuklar ve aileleriyle ancak hem Kürtçe hem Arapça bilen tercümanlar yardımıyla iletişim kurabilmektedir.

Türk öğretmenlerin dil öğretiminde çocukların seviyelerin aynı olmamasından kaynaklanan sorunlar yaşadıkları tespit edilmiştir. Öğrencilerin temel becerilerde farklı noktalarda olmalarının öğretmenler tarafından zorlanılan bir diğer nokta olduğu sonucuna varılmıştır.

Öğretmenlerin dil sorununu en aza indirmek için ders esnasında konuları en somut ve sade şekliyle anlatmaya çalıştıkları ve konuşma hızlarını yavaşlattıkları ayrıca önemli bir konuda kilit kelimelerin Arapçalarını öğrenip ders esnasında anlatımı kolaylaştırmaya çalışmak gibi kendi yöntemlerini geliştirdikleri tespit edilmiştir.

Yapılan görüşmeler ve gözlemler sonucunda Türkçe öğretmenlerinin yaptıkları Türkçe sınavlarında Kürt öğrencileri Arap öğrencilere göre daha başarılı gördükleri sonucuna varılmıştır. Neden olarak ise Arapçanın Kürtçeye göre dil yapısı ve ortak kelime dağarcığının Türkçeden daha uzak olduğu vurgusunda bulunulmuştur.

Edinilen bulgulara göre Türkçeyi öğrenip Türkiye'ye adapte olmuş öğrenciler ile Türkçeyi henüz öğrenememiş ve Türkiye'ye henüz adapte olamamış öğrencilerin arasındaki temel farkların öncelikli olarak öğrencinin Türkçe diline istek duyup duymaması, Türkiye’ye veya okula geliş tarihlerinin yeterli olup olmaması, Türk arkadaşlarının olup olmaması, ailelerin Türkçeye ve 
çocuklarının eğitimine önem verip vermemesi, ailelerin farklı bir ülkeye göç etmeyi düşünüp düşünmemesi, öğrencinin yaşının dil öğretimi için uygun olup olmaması, öğrencinin Suriye’yi özleyip özlememesi, ailelerin öğrencinin bakımı ve beslenmesi gibi temel ihtiyaçları karşılayacak ekonomisinin olup olmaması ve öğrencinin savaşa dair bir travmasının olup olmaması gibi faktörlerden kaynaklandığı sonucuna varılmıştır.

Ulaşılan bu sonuca benzer olarak Boylu ve Işık (2019) öğrencilerin kültürden doğan farklılıkları kabul etmemeleri, Türkiye'den gideceklerini düşünmeleri ve etraflarında sürekli Arapça konuşan insanların bulunmasının öğrencilerin dil gelişimlerini etkilediği fakat en önemli etkenin dili öğrenmeye istekli olup olmamalarından kaynaklandığı sonucuna varmıştır. Beyhan (2018) öğrencilerin konuyu kavrama niteliği ve sürecinin öğrencilerin yaşına göre değişkenlik gösterdiği ve derslerin öğrencilerin zeka tiplerine göre işlendiği sonucuna varılmıştır. Yapıc1 (2019) ise öğrencilerin dile karşı ilgilerinin yaş ve tecrübelere göre farklılık gösterdiğini tespit etmiştir.

Bazı öğrencilerin okula daha geç gelmeye başlamasına rağmen ilk gelenlerden daha fazla yolu hızlı bir şekilde kat ettiği, en önemli faktörün öğrencinin dile istekli olması gerektiğine de vurgu yapılmıştır.

\section{Uyum}

Türk öğretmenlerin geçici eğitim merkezinde eğitim vermeye başladıktan sonra Arapçaya ilgilerinin uyandığı, Arapçayı anlamaya başladıkları ve bu durumun da öğrenci ilişkilerine olumlu yönde yansıdığı tespit edilmiştir.

Türk öğretmenlerin çok kültürlü ortamda kendilerini iyi hissettikleri ve Suriye ve Suriyelilere dair önceden nötr fikirlere sahipken GEM' de öğretmenliğe başladıktan sonra Suriyelileri sevmeye başladıkları yönünde sonuçlara ulaşılmıştır. Türk öğretmenlerin kendilerini Suriyelilerden genel anlamda sorumlu tutmaları, sadece okul içinde değil okul dışında da Suriyelilerin problemlerini çözmeye yönelik davranışları öğretmenlerin görevlerini benimsediklerini göstermektedir.

Türk ve Suriyeli öğretmenlerin uyum noktasında gösterdikleri en büyük ortak etken din ve dinden doğan kültürel benzerlikler, adetler ve yemek kültürünün benzerliği olmuştur. Öğretmenlerin birbirlerinin kültürünü tanımaya yemeklerden başlamıştır.

Suriyeli öğretmenlerin verilerinde uyum noktasında en çok zorlandıkları noktaların ise İstanbul'un düşündüklerinden daha pahalı ve kalabalık olması, işlerde maaşların çalışma saatlerine göre oldukça az olması gibi faktörler olduğu saptanmıştır. Suriyeli öğretmenlerin uyumlarını sağlamalarında ise daha önce Türkiye'ye yerleşmiş akrabaları veya Arapça bilen komşuları yardımcı olmuştur.

Suriyeli öğretmenlerin Türkiye'ye uyumları dil problemini aşmalarıyla doğru orantılı olmuştur. Savaş bittiğinde Suriye'ye dönmeyi düşünenler Türkiye'nin pahalıllğ 1 ve vatan hasreti gibi gerekçeler 
gösteriyorken Suriye'ye dönmeyi düşünmeyenlerin en büyük gerekçesi savaşın Suriye'yi çok gerilettiği ve Suriye'nin yaşanacak bir hal alabilmesi için epey zamana ihtiyaç duyduğunu düşünmeleri olmuştur.

\section{Geçici Eğitim Merkezlerinde Karşılaşılan Eksiklikler ve Yasal Sıkıntılar}

Öğretmenlerin geçici eğitim merkezinde karşılaştıkları en büyük eksikliğin materyal olduğu sonucuna varılmıştır. Öğretmenler açısından materyal eksikliği ve bozulan materyallerin hemen tamir edilememesinin eğitimi aksattığı sonucuna varılmıştır. Öğretmenlerin özellikle dil öğretiminde materyalin önemine değinmeleri ve materyal veya görsel olmadığı takdirde öğrencilerin dersi çok fazla bir istekle dinlemediklerini gözlemledikleri vurgulanmıştır.

Boylu ve Iş1k (2019) gerçekleştirdikleri araştırmada öğretmenlerin ders esnasında en büyük engellerinden birinin materyal eksikliği olduğunu belirtmiştir. Usta, Arıkan, Şahin ve Çetin (2018) da öğretmenlerle gerçekleştirdikleri görüşmelerde materyal ve ders araç-gereçlerinin eksikliğinin önemli bir engel olduğunu belirtmişlerdir. Moralı (2018) ve Gencer (2017) ise derslerdeki bu materyal eksikliğinin eğitimin verimini önemli bir ölçüde engellediği sonucuna varmıştır. Beyhan (2018) ve Sönmez (2019) da araştırmalarında materyal eksikliğinin geçici eğitim merkezlerinde karşılaşılan önemli eksiklerden olduğunu tespit etmişlerdir.

Geçici eğitim merkezlerinde karşılaşılan bir diğer eksik ise ailelerin çocuklarının eğitimini önemsememeleridir. Öğretmenlerin dönem içerisinde yaptıkları veli toplantılarına katılımın çok az olması, çocukların öğrendiklerini eve gittiklerinde pekiştirmelerine yardım edecek bir aile profiline sahip olmadıkları sonucuna varmamıza neden olmuştur. Ailelerin çocukların eğitimlerine önem vermediklerini gösteren bir diğer nokta ise geçici eğitim merkezinde devamsızlığın oldukça fazla olmasıdır. Öğretmenlerin aileler noktasında değindiği bir diğer nokta ise geçici eğitim merkezine bıraktıkları iletişim numarası ve adres bilgilerinin yanlış olmasıdır. Ailelerin bu tutumunun zamanla öğrencilerin eğitime bakışına da etki edeceği ön görülebilmektedir.

Usta, Arıkan, Şahin ve Çetin (2018) ve Yapıcı (2019) Ailelerin eğitime karşı tutumlarına dair ailelerin çocuklarının eğitimine önem vermediği ve özellikle ekonomik imkânsızlıklar dolayısıyla çocuklarını okula göndermektense ya işte çalışmalarını tercih ettikleri ve ya kız çocuklarının erken yaşta evlendirdikleri sonucuna varmıştır. Moralı (2018) ve Sönmez (2019) Aile işbirliğinin olmamasının ve ailelerin düzenlenen toplantılara katılmamalarının geçici eğitim merkezlerinde karşılaşılan önemli sorunlardan biri olduğunu vurgulamıştır. Aynı şekilde Boylu ve Işık (2019) da devamsızlığın geçici eğitim merkezlerinde karşılaşın problemlerden biri olduğunu belirtmiştir.

Geçici eğitim merkezinde bir diğer eksiğin kitapların dağıtımından kaynaklandığı sonucuna varılmıştır. Öğretmenler kitapların çok geç geldiğini dile getirmiştir. Dönem ortalarına doğru gelen ders kitaplarının ve dönem başında verilen öğrenci sayısının zamanla artmasından dolayı yeni gelen öğrencilerin kitapsız kalması gibi durumların yaşandığı tespit edilmiştir. 
Ders kitaplarının geç gelmesinin eğitimi ne şekilde etkilediği hakkında Gencer (2017) ders kitaplarının daha planlı bir şekilde dağıtılmasının öğrencilerin okula uyumunun dönem başı itibariyle başlatacağ1 ve süreci kolaylaştıracağ1 sonucuna ulaşmıştır. Kaya (2019) ise öğretmenlerin karşılaştıkları güçlüklerde materyal eksikliğine ek olarak kitapların dağıtımında problemlerin yaşandığını ve ayrıca kitapların öğrencilerin dil düzeylerine uygun olmadığını belirten sonuçlara ulaşmıştır.

Bir diğer nokta ise öğrencilerin Suriye'den sonra eğitime ara vermelerinden kaynaklanan yaş1 büyük öğrencilerin küçük sınıflarda yer alıyor olmalarıdır. Savaştan sonraki göç dönemi ve ailelerin düzenli olarak bir bölgeye yerleşmeleri yaklaşık en az bir ya da iki senelerini almaktadır. Bu süre genellikle öğrencilerin göç sürecinde eğitim almadıklarından kaynaklanmaktadır. Gencer (2017) öğrencilerin bu süreçte ekonomik sıkıntılar yaşadığı ve bu durumdan dolayı da eğitimlerine devam edemediklerine değinmiştir.

Suriyeli öğretmenler Suriyeli çocukların Suriye'deyken daha disiplinli davrandıklarını fakat Türkiye de daha şımarık ve rahat bir tavır sergilediklerini söylemişlerdir. Bu durum geçici eğitim merkezinde disiplin eksikliğinin varlığını göstermektedir. Bu durumdan kaynaklı öğrencilerin Suriyeli öğretmenlere daha saygılı davranırken Türk öğretmenlerine karşı daha rahat davrandıkları sonucuna varılmıştır.

Boylu ve Işık (2019) da araştırmalarının sonucunda öğrencilerin Suriyeli öğretmenlere Türk öğretmenlerine kıyasla daha saygılı ve dikkatli davrandıkları sonucuna varmıştır. Moralı (2018) Türkçe öğretiminde devamsızlık ve disiplinsizliğin eğitim sürecine önemli derecede zarar verdiği tespitinde bulunmuştur.

Suriyeli öğretmenlerin geçici eğitim merkezini Suriye'deki okullarla karşılaştırdıklarında akıllı tahta konusunda daha donanımlı buldukları fakat materyal ve kitap, kütüphane gibi noktalarda ise eksik gördükleri tespit edilmiştir.

Öğreticilerin işledikleri konular arasında ünite, tema noktalarında benzerliğin olmaması, öğretmenlerin öğrencilerin dil düzeylerine göre eğitim verdiğini desteklese de öğretmenlerin aynı planı uyguluyor olmaları öğretmenlerin plan ve program noktalarında yetersiz olduğu sonucunu doğurmaktadır. Aynı şekilde Kaya (2019) da profesyonel bir programın olmamasının ve eğitimin öğretmenlerin inisiyatifinde gerçekleştirilmesinin eğitim açısından olumsuz bir durum oluşturduğu sonucuna varmıştır. Gencer (2017) de eğitimin hassas bir şekilde planlanması gerektiğini belirtmiş, Sönmez (2019) ise aynı doğrultuda geçici eğitim merkezlerinde verilen eğitimlerde ders planı ve programlamanın eksik olduğunu vurgulamıştır.

Geçici eğitim merkezinin bir plazanın ara katında bulunuyor olmasının öğrencilerin ve öğretmenlerin hareket alanını kısıtladığını ve teneffüs aralarında yeteri kadar temiz hava alamamalarına neden olduğu sonucuna varılmıştır. 


\section{Yasal sıkıntılar}

Türkçe öğreticisi öğretmenlerin yasal noktada yaşadıkları sıkıntıların başında tatillerinin az olması gelmektedir. Öğretmen ve öğrencilerin tatillerinin az olmasının eğitim ve öğretimi sağlıksız hale getirdiği, öğretmen ve öğrencilerinin performansını en aza indirdiği sonucuna varılmıştır.

Mehmet Emin Usta (2018) yaptığı araştırmada maddi imkânların kısıtlı olmasının öğretmenlerin performansını olumsuz yönde etkilediği sonucuna varmıştır. Aynı zamanda Suriyeli öğretmenlerin özlük haklarını yeterli görmedikleri ve maaşlarını da yetersiz gördükleri için ikinci bir işi aramak zorunda kaldıkları sonucuna da varmıştır. Aynı şekilde Moralı (2018) ve Balkar, Şahin ve Işıklı Babahan (2016) da araştırmalarında öğreticilerin maaşlarının azlığı ve öğretmenlerin yasal haklarının kısıtlı olmasının eğitim sürecini olumsuz yönde etkilediği sonucuna varmıştır.

Öğretmenler sık sık yer değiştirmekten şikâyetçi olduklarını ve bu durumun aile hayatlarına da olumsuz şekilde yansıdığını belirtmişlerdir. Öğretmenlerin geçici eğitim merkezleri kapatıldıktan ve proje sona erdikten sonra işsiz kalma kaygılarının performanslarını olumsuz yönde etkilediği ifade ettikleri ve gözlemlenmiş noktadır. Öğretmenler odasında, kendi aralarında devamlı olarak proje bitiminde kendilerinin kadroya alınabileceğine dair muhabbet ettikleri gözlemlenmiştir, yıllarca bu işte çalışmanın kendilerine kattığı tecrübelerin değerlendirileceği konusunda olumlu bir tutuma sahip oldukları tespit edilmiştir. Aynı şekilde Ayşe Kaya (2019) da geçici eğitim merkezindeki öğretmenlerle gerçekleştirdiği araştırmasında öğretmenlerin işlerinin geçici olmasının ve proje sonunda işsiz kalma korkularının iş verimliliğini düşürdüğü sonucuna varmıştır.

Suriyeli öğretmenler ise kendilerinin Suriye'deyken birçok hakka sahip olduklarını ve Türkiye'de aynı şekilde kendilerine emeklilik hakkı, öğretmen kartı ve maaşlarında iyileştirme, işlerinin devamlı olmasını istediklerini ve İmam Hatip liselerindeki Arapça dersleri kendilerinin vermeyi istedikleri sonuçlarına ulaşılmıştır.

\section{Mesleki Deneyim ve Eğitim Eksikliği}

Edinilen verilere göre öğreticilerin hiç biri lisansüstü öğrencisi değildir. Fakat özellikle Türk öğreticilerin tecrübelerini kullanabilmek için lisansüstü eğitim düşündükleri sonucuna varılmıştır.

Öğreticilerin proje kapsamında çalışmaya başlamadan önce 15 günlük bir eğitim aldıkları fakat bu eğitimin teorik bilgileri içermesinden dolayı çalışma hayatlarına bir fayda sağlamadığı sonucuna varılmıştır. Boylu ve Işsk (2019) da öğretmenlerin kendilerine verilen eğitimleri özellikle teorik bilgileri içermesi nedeniyle faydalı bulmadıkları sonucuna ulaşmıştır.

Öğreticilerin projede çalıştıktan bir süre sonra İstanbul Üniversitesinde katıldıkları Yabancılara Türkçe Öğretimi Sertifika Programı öğreticiler tarafından sahada uygulanabilecek pratik bilgiler içerdiği için faydalı bulunduğu tespit edilmiştir. 
Öğretmenlerin mesleki eksiklerini sahada çalışarak kapatmaya çalıştıkları fakat tecrübelerini değerlendirebilecekleri ve yeni tecrübeler kazanabilecekleri uygulama ve projelere dair bilgilerinin olmadığ1 sonucuna varılmıştır.

Geçici eğitim merkezlerinde karşılaşın en büyük eksiklerden biri sınıf yönetiminin eksikliği ve öğrenci disiplinin sağlanamaması oluşturmaktadır. Bu sonuç özellikle Türkçe öğreticilerinde ekstra eğitimin ve tecrübe eksikliğinin olduğunu göstermektedir. Ulaşılan bu sonuca eş olarak Balkar, Şahin ve Işıklı Babahan (2016) da araştırmalarında Öğreticilerin sınıf yönetimi noktasında eğitime ihtiyaçlarının olduğu ve bu eğitimlerin özellikle Türkçe öğreticileri açısından daha acil bir ihtiyaç olduğuna vurgu yapmıştır.

Öğreticilerin birbirleriyle daha çok okul içerisinde yaptıkları etkinlikleri paylaşarak veya sosyal medyalardaki paylaşımları takip ederek tecrübe alış verişinde bulundukları ve tecrübe noktasındaki eksikliklerini gidermek için alana dair basılan tüm kaynakları edindikleri, Türkçe öğretimiyle alakalı videoları izledikleri, konunun ana kelimelerinin Arapçasını öğrenerek anlatımı kolaylaştırmaya çalıştıkları sonucuna varılmıştır.

Suriyeli öğreticilerin lisansüstü eğitime dair bilgilerinin oldukça az olduğu ve ekonomik sebepler, iş yoğunluğu gibi nedenlerden dolayı lisansüstü eğitimlerini ertelediklerine dair sonuca varılmıştır.

\section{Öneriler}

- Ulaşılan verilerde geçici eğitim merkezindeki dil probleminin sadece Türkçe ve Arapça dillerini konuşanlar arasında yaşanmadığı aynı zamanda Kürt öğrenci ve velilerinin de ekstra dil problemi yaşadığı tespit edilmiştir. Bu doğrultuda Türkiye'de eğitim veren ve temel diğer dersleri Arapça olan geçici eğitim merkezlerindeki Kürt öğrencilerin yaşadıkları sıkıntılar üzerine bir araştırma yapılabilir.

- $\quad$ Öğretmenlerden alına veriler ışı̆̆ında geçici eğitim merkezinde gerek öğrencilerin devamsızlık problemi gerekse veli toplantılarına katılımların az olması Suriyeli ailelerin eğitime çok önem vermediğini göstermiştir. Ailelerin bu tutumunun nedenleri hakkında bir araştırma yapılabilir.

- Suriyeli öğretmenler öğrencilerin Suriye'deyken daha disiplin davrandıklarını belirtmiştir. Öğrencilerin bu disiplini Türkiye'de neden devam ettirmedikleri üzerine bir araştırma yapılabilir.

- $\quad$ Araştırma sadece öğretmenlerle yapılmıştır. Öğrencileri ve idarecileri de kapsayan ve geçici eğitim merkezindeki eğitimi daha geniş bir çerçevede inceleyen bir araştırma yapılabilir.

- $\quad$ Araştırma daha fazla öğretmen ve daha farklı şehirde yapılarak genişletilebilir. 
- $\quad$ Öğrencilerin göç esnasında eğitimlerine ara vermelerinden kaynaklı olarak geçici eğitim merkezlerinde yaş ve sınıf düzeyleri arasındaki farklılıklardan doğan sıkıntılar hakkında araştırmalar yapılabilir.

- Yapılacak araştırmalarda sadece geçici eğitim merkezindeki öğretmenlerle sınırlı kalınmayıp devlet okullarındaki Türkçe öğreticileri ve Suriyeli öğretmenlerle de çalış1labilir.

- $\quad$ Araştırmada sadece sınıf öğretmenliği mezunlarının tecrübelerine yer verilmiştir. Yapılacak olan araştırmalar Türkçe öğretmenliği ve Türk Dili ve Edebiyatı mezunu Türkçe öğreticileri ve Suriye'de diğer branşlardan mezun Suriyeli öğretmenlerin tecrübelerinden de faydalanılabilir.

\section{KAYNAKÇA}

Balkar, B., Şahin,S., Işıklı Babahan, N., (2016). Geçici eğitim merkezlerinde görev yapan suriyeli öğretmenlerin karşılaştıkları sorunlar. Eğitimde Kuram ve Uygulama, 12(6), 1290-1310.

Baykara Acar, Y.(2004). Cinsel suçtan hükümlü çocukların yaşam öyküsü çallşması ve grupla sosyal hizmet uygulaması ( Doktora tezi). Hacattepe Üniversitesi, Sosyal Bilimler Enstitüsü. Ankara.

Beyhan, D. (2018). Suriyeli öğrencilerin türk eğitim sistemine entegrasyonu projesi kapsamında geçici eğitim merkezlerinde görev yapan dil ögrreticilerinin dil öğretirken karşılaştıkları sorunlar ve çözüm önerileri (Yüksek lisans tezi). Siirt Üniversitesi, Sosyal Bilimler Enstitüsü, Siirt.

Boylu, E. ve Işık, P. (2019). Suriyeli mülteci çocuklara yabancı dil olarak türkçe öğretenlerin yaşadıkları durumlara ilişkin görüşleri. GEFAD / GUJGEF, 39, 895-936.

Bruner, J. (1987). Life as Narrative. Social Research, 54(1), 11-32. Retrieved April 20, 2020, from www.jstor.org/stable/40970444

Eryaman, M. Y. \& Evran, S. (2019). Syrian Refugee Students' Lived Experiences at Temporary Education Centres in Turkey. In Khalid Arar, Jeffrey S. Brooks, Ira Bogotch (Eds) Education, Immigration and Migration: Policy, Leadership and Praxis for a Changing World. Emerald Publishing Limited.

Gencer, Tahir E. (2017). Göç ve eğitim ilişkisi üzerine bir değerlendirme: suriyeli çocukların eğitim gereksinimi ve okullaşma süreçlerinde karşılaştıkları güçlükler. Uluslararası Sosyal Araştırmalar Dergisi, 10, 839- 851 .

Kaya, A. (2019). Suriyeli mülteci çocukların eğitimi üzerine bir araştırma: geçici eğitim merkezleri ve müfredatları (Yüksek lisans tezi). Marmara Üniversitesi, Orta Doğu ve İslam Ülkeleri Araştırmaları Enstitüsü, İstanbul.

Keskinkılıç Kara, Sultan B., Şentürk Tüysüzer, B.(2017). Sığınmacı öğrencilerin eğitimi sürecinde yaşanan sorunlara ilişkin yönetici, öğretmen ve veli görüşleri. Akademik Sosyal Araştırmalar Dergisi, 5, 236250.

Moralı, G. (2018). Suriyeli mülteci çocuklara türkçenin yabancı dil olarak öğretiminde karşılaşılan sorunlar. Uluslararsı Toplum Araştırmaları Dergisi, 8(15), 1426-1449.

Özdemir,E. (2017). Suriyeli mülteciler krizinin türkiye'ye etkileri. Ankasam Uluslararası Kriz ve Siyaset Araştırmaları Dergisi, 1 (3) , 114-140. 
Sönmez, R.(2018). Yönetici ve öğretmen görüşlerine göre geçici eğitim merkezlerinin sorunlarl ve çözüm önerileri (Yüksek lisans tezi). Sabahattin Zaim Üniversitesi, Sosyal Bilimler Enstitüsü, İstanbul.

UNICEF\&Gap Çalıştay Final Raporu (2016). Suriyeli Çocuk ve Gençlerin Güçlendirilmesi İçin Çalışma Alanlarının Belirlenmesi Çalıştayı. 4-5 Mayıs 2016. Hilton Otel/ Şanlıurfa.

Usta, Mehmet E., Arıkan,İ., Şahin,Y. ve Çetin,Mustafa S. (2018). Suriyeli eğitimcilerin gözünden geçici eğitim merkezlerinde karşılaşılan sorunların incelenmesi. Mukaddime, 9(1), 173-188.

Yapıc1, S.(2019). Suriyeli ögretmen ve veli görüşlerine göre geçici eğitim merkezlerinin değerlendirilmesi: nitel bir araştırma (Yüksek lisans tezi). İstanbul Sabahattin Zaim Üniversitesi, Sosyal Bilimler Enstitüsü, İstanbul.

Yıldırım, A.ve Şimşek, H. (2008). Sosyal bilimlerde nitel araştırma yöntemleri. Ankara: Seçkin Yayınları 